\title{
Meso- and Macrozooplankton Communities in the Weddell Sea, Antarctica
}

\author{
Elisabeth Boysen-Ennen* and Uwe Piatkowski** \\ Alfred-Wegener-Institut für Polar- und Meeresforschung, Columbusstrasse, D-2850 Bremerhaven, Federal Republic of Germany \\ Received 26 October 1987; accepted 21 January 1988
}

Summary. The present paper describes composition and abundance of meso- and macrozooplankton in the epipelagic zone of the Weddell Sea and gives a systematic review of encountered species regarding results of earlier expeditions. Material was sampled from 6 February to 10 March 1983 from $R V$ Polarstern with a RMT $1+8 \mathrm{~m}$ (320 and $4500 \mu \mathrm{m}$ mesh size). In agreement with topography and water mass distribution three distinct communities were defined, clearly separated by cluster analysis: The Southern Shelf Community has lowest abundances (approx. 9000 ind. $/ 1000 \mathrm{~m}^{3}$ ). Euphausia crystallorophias and Metridia gerlachei are predominating. Compared with the low overall abundance the number of regularly occurring species is high (55) due to many neritic forms. Herbivores and omnivores are dominating $(58 \%$ and $35 \%$ ). The North-eastern Shelf Community has highest abundances (about 31000 ind. $/ 1000 \mathrm{~m}^{3}$ ). It is predominated by copepodites I-III of Calanus propinquus and Calanoides acutus $(61 \%)$. The faunal composition is characterized by both oceanic and neritic species (64). Fine-filter feeders are prevailing $(65 \%)$. The Oceanic Community has a mean abundance of approximately 23000 ind. $/ 1000 \mathrm{~m}^{3}$, consisting of 61 species. Dominances are not as pronounced as in the shelf communities. Apart from abundant species like Calanus propinquus, Calanoides acutus, Metridia gerlachei, Oithona spp. and Oncaea spp. many typical inhabitants of the Eastwind Drift are encountered. All feeding types have about the same importance in the Oceanic Community.

\section{Introduction}

In spite of numerous zooplankton studies in the Southern Ocean collections from waters close to the Antarctic con-

\footnotetext{
Present addresses:

* Institut für Polarökologie, Universität Kiel, Olshausenstrasse 40/60, D-2300 Kiel, Federal Republic of Germany

** Institut für Meereskunde, Abteilung Fischereibiologie, Düsternbrooker Weg 20, D-2300 Kiel, Federal Republic of Germany
}

tinent are very scarce, because large ice-fields impede oceanographic research. However, during the British Antarctic Terra Nova Expedition 1910-1913 the fauna of the Ross Sea was investigated south to $78^{\circ} \mathrm{S}$ (e.g., Farran 1929). A corresponding investigation in the Weddell Sea which extends to $78^{\circ} \mathrm{S}$ in the Atlantic sector of the Southern Ocean has not been carried out so far.

Taxonomy of Antarctic zooplankton has been studied sufficiently, and except in the Weddell Sea and many coastal regions, the geographical distribution of most taxa is known (e.g., Mackintosh 1934; Baker 1954; Marr 1962 among others). Antarctic zooplankton communities, however, were described only by few authors (Hardy and Gunther 1936; Rakusa-Suszczewski 1983; Hopkins 1985a), and information on seasonal development is even more scarce (Voronina 1970, 1972a). Although many Antarctic expeditions reached the northern Weddell Sea, zooplankton research south of $70^{\circ} \mathrm{S}$ was virtually non-existent before $1976 / 1977$. The only exceptions are vertical net samples from the Deutschland collected during her ice-drift $(1911 / 1912)$. From these samples the occurrence of appendicularians (Lohmann 1928), polychaetes (Augener 1929), hydromedusae (Thiel 1931) and chaetognaths (Bollmann 1934) was described. Zooplankton collections during four Polarsirkel expeditions (1976-1981) showed an unexpected high species diversity in the pelagic ecosystem of the high-Antarctic shelves. The euphausiid Euphausia crystallorophias, the copepods Ctenocalanus vanus and Oithona spp. and the postlarvae of the Antarctic silverfish Pleuragramma antarcticum were abundant components of the zooplankton (e.g., Fevolden 1979, 1980; Hempel and Hempel 1982; Hempel et al. 1983; Kaczmaruk 1983; Keller 1983). Recently Hubold and Hempel (1987) for the first time studied the seasonal variability of zooplankton in the southern Weddell Sea by comparing the abundances of 18 frequently occurring zooplankton taxa of varying taxonomic level. A comprehensive and quantitative analysis of the zooplankton and its community structure related 
to the water masses and the current system was, however, still lacking.

The aim of the present investigation is to fill this gap by surveying the summer distribution of the epipelagic zooplankton on a large scale in the inner Weddell Sea, to sample a broad size spectrum of zooplankton by combining RMT $1(320 \mu \mathrm{m})$ and RMT $8(4500 \mu \mathrm{m})$ samples, and to analyze its composition considering the synecological aspect. Due to stratified sampling we describe horizontal and vertical distribution of the prevailing zooplankton species. Regarding earlier zooplankton studies carried out in the Weddell Sea and in adjacent waters the paper gives a systematic review on regularly occurring species. Another main objective is the analysis of zooplankton communities. In order to decide whether topography, water masses and current systems separate distinct zooplankton communities, the survey covered the open sea as well as the polynyas close to the continent. These communities will be characterized by their faunal components and by their different trophic structures.

\section{Material and Methods}

Zooplankton was collected in February and March 1983 from $R V$ Polarstern using a RMT $1+8 \mathrm{~m}$ (multiple Rectangular Midwater Trawl). A detailed description of the net is given by Baker et al. (1973), and Roe and Shale (1979). It consists of two net systems fishing synchronously with different mesh sizes ( 320 and $4500 \mu \mathrm{m}$ ) and mouth openings $\left(1 \mathrm{~m}^{2}\right.$ and $8 \mathrm{~m}^{2}$ ). This RMT equipped with three net pairs opened and closed sequentially by hydroacoustic transmission. Standard oblique hauls were made in the depth strata $300-200 \mathrm{~m}, 200-50 \mathrm{~m}$ (thermocline) and 50-0 $\mathrm{m}$. However, for community analysis the three layers were treated as one single oblique haul. Filtered water volumes were calculated considering net speed, net angle and flow data according to Roe et al. (1980). Station lists are published by Drescher et al. (1983).
From a total of 39 hauls carried out in the inner Weddell Sea we have chosen 32 hauls with comparable fishing depths to study community analysis. The majority of the hauls was done in the summer polynya parallel to the shelf ice barrier (Fig. 1). Consequently 22 of the stations were located in shelf areas, the other ten in oceanic waters. Sampling took place exclusively during daylight from 6 February to 10 March 1983. Samples were preserved in $4 \%$ buffered formaldehyd sea water solution. In case of RMT 8-samples all organisms $>5 \mathrm{~mm}$ were counted and identified to species level ignoring copepods, euphausiid larvae, and small polychaetes. Nearly all RMT 1-samples were split with a Wiborgsubsampler down to $1 / 10$ to count larval euphausiids, copepods, ostracods, juvenile polychaetes and small gastropods from the aliquot. All other groups were counted from the entire sample. The plankton species of the RMT 1-samples were identified down to species and/or stage level (Table 1), however the copepodites I-III of Calanus propinquus and Calanoides acutus were not separated. According to Heron and Bowman (1971) the species name Ctenocalanus citer is used instead of Ctenocalanus vanus. Therefore earlier findings of Ctenocalanus vanus from Antarctic waters (e.g., Kaczmaruk 1983; Hopkins 1987) are probably Ctenocalanus citer. In the controversial pteropod taxonomy we used the species names according to Van der Spoel (1967). Chaetognaths and tomopteriids were counted in total, with species identification only of the RMT 8-samples. Unpublished data on fish larvae were provided by G. Hubold (personal communication). Species abundance was calculated in $\mathrm{n} / 1000 \mathrm{~m}^{3}$. Maps of the geographical distribution of most species and full details on their vertical distribution are available in the doctoral theses of the authors (Boysen-Ennen 1987; Piatkowski 1987). Abundances of species of both net systems were compared, and in each case the higher value was considered to adjust effects of net selection.

Agglomerative hierarchical cluster analysis (Bölter et al. 1980; Bölter and Meyer 1986) was applied to differentiate zooplankton communities. Similarities between stations were expressed by Canberra metric (Lance and Williams 1967), which groups the stations according to both presence and abundance of species. Species which occurred only once or twice in the samples were excluded from community analysis. Sampling, subsampling and sorting procedure as well as data analysis were described in detail by Boysen-Ennen (1987) and Piatkowski (1987).

We have classified the zooplankton species into four trophic groups considering the prevailing feeding habit: fine-filter feeders, coarse-filter feeders, omnivores (mixed mode feeders), and carnivores (grasping,

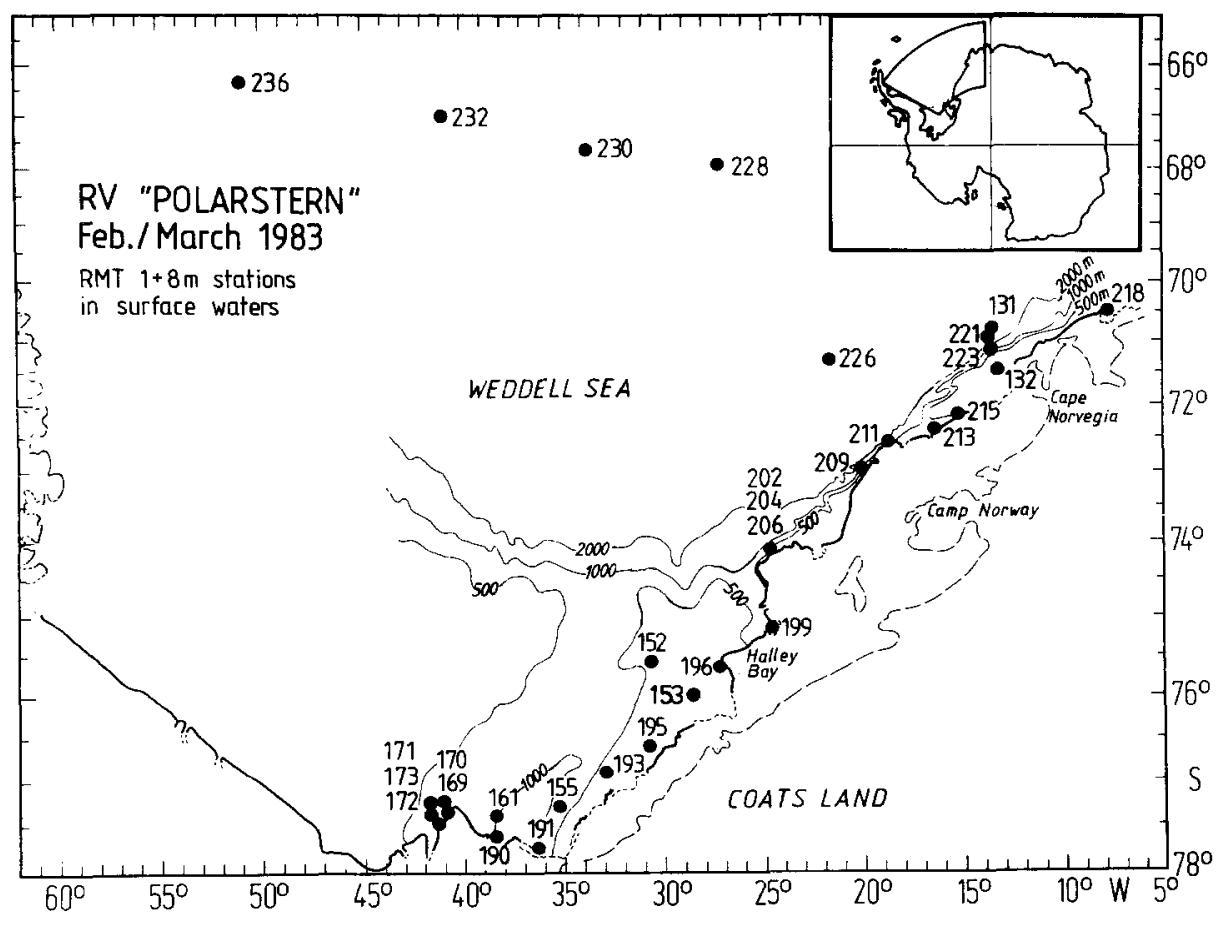

Fig. 1. Geographical locations and RMT sampling stations along the main route of the 1983 Polarstern expedition in the Weddell Sea 
biting and sucking predators). Although carnivores are known to feed on phytoplankton during their early life phases, e.g. the cyclopoid genera Oithona and Oncaea (Petipa et al. 1970; S. B. Schiel, personal communication). We considered the feeding habit of adult forms only. For example, fine-filter feeders are the copepodites I-III of the Calanidae (Marshall and Orr 1956) and the calyptopis stages of Euphausia crystallorophias (Kittel and Ligowski 1980). Coarse-filter feeders are adults and copepodites IV-V of Calanus propinquus and Calanoides acutus (Schnack 1983), Ctenocalanus citer (S. B. Schiel, personal communication) and Rhincalanus gigas (Andrews 1966), the pteropod Limacina helicina (Morton 1954), furciliae, juveniles and adults of Euphausia crystallorophias (Kittel and Ligowski 1980) and Euphausia superba (e.g., Kils 1983). The copepod Metridia gerlachei, the euphausiid Thysanoessa macrura, the ostracods Conchoecia spp. and the Scolecithridae are omnivorous (Wickstead 1962; Hopkins 1985b). Chaetognaths and Euchaetidae (Hopkins 1985 b), the copepods Oithona spp. and Oncaea spp. (Timonin 1973), siphonophores (Biggs 1977), amphipods (e.g., Harbison et al. 1977; Slattery and Oliver 1986) and the early life stages of the Antarctic silverfish Pleuragramma antarcticum (Kellermann 1987) are carnivorous.

\section{Hydrography}

The western Weddell Sea is covered by ice all year round. In the eastern Weddell Sea the northern part is ice-free in summer and along the ice shelf barrier there are large polynyas extending to the Gould Bay in the south. The time of ice-free water decreases from several months in the north to few weeks in the south (Strübing 1982), and the successive melting process likely causes seasonality in the pelagic community. High primary production was measured in leads and polynyas during austral summer (e.g., El-Sayed and Taguchi 1981; Von Bröckel 1985), and besides bottom topography and water masses it has an important influence on the plankton distribution.

The central Weddell Sea is characterized by a large oceanic basin with an average depth of $4400 \mathrm{~m}$ (Carmack and Foster 1977). An extensive, deep shelf area is adjacent to the south interrupted by various innershelf trenches. Bottom topography, water temperature and salinity as measured along the coast-parallel main route of the 1983 Polarstern expedition (H.P. Koltermann, personal communication), are summarized in a depth profile (Fig. 2). The continent-near surface currents in the southern Weddell Sea as outlined by Carmack and Foster $(1975,1977)$ are shown in Fig. 3.

So-called Ice Shelf Water with temperatures as low as $-2{ }^{\circ} \mathrm{C}$ (Carmack and Foster 1975) covered by a warmer surface layer $\left(-1.8^{\circ}\right.$ to $\left.-0.5^{\circ} \mathrm{C}\right)$ characterizes the coastal waters (Fig. 2). Due to melting processes in summer, the surface layer has lower salinities, supporting stabilization of the water column (Fig. 2). At the continental slope there is a coastal convergence which separates the Shelf Water from the water of the Eastwind Drift carrying the Warm Deep Water with temperatures above $0^{\circ} \mathrm{C}$. Since

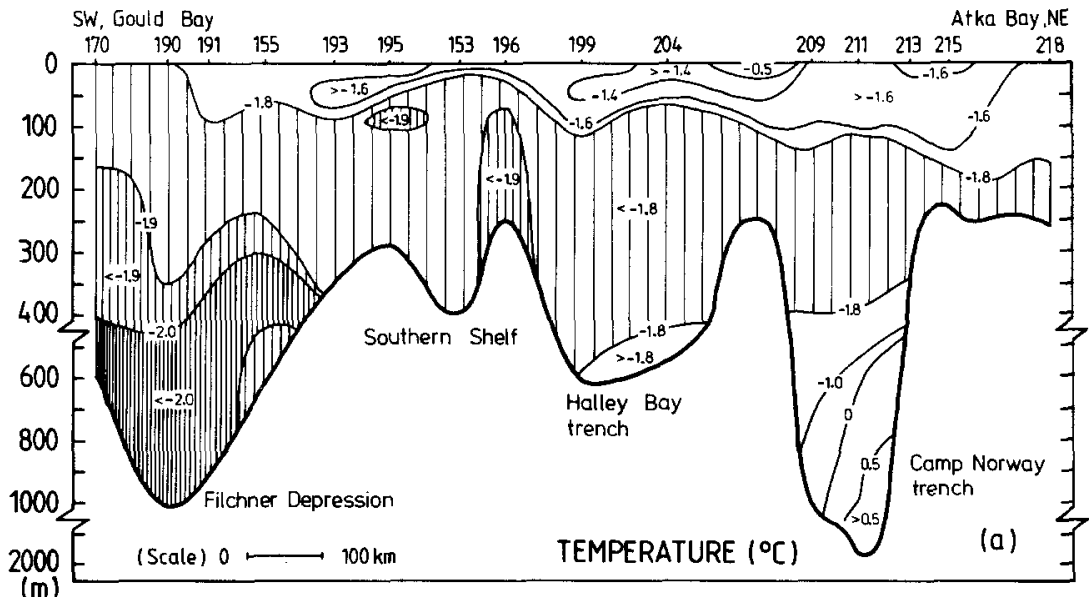

(m)

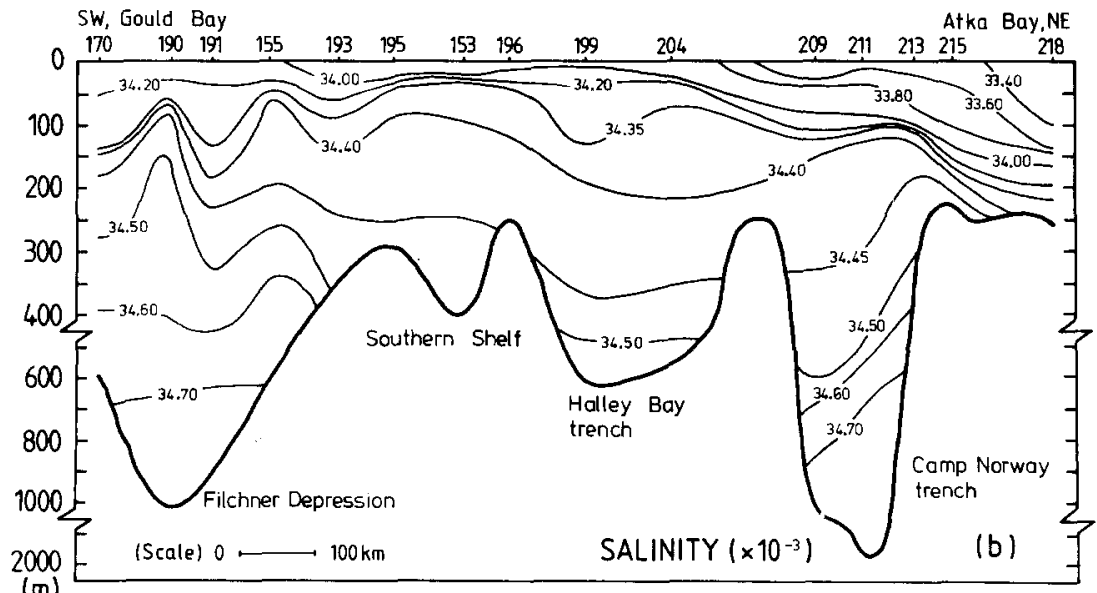

Fig. 2a,b. Coast-parallel depth profiles along the main route of the 1983 Polarstern expedition showing station numbers, bottom depth, and innershelf depressions between Gould Bay in the SW and Atka Bay in the NE. a water temperature, b salinity as measured in February 1983 


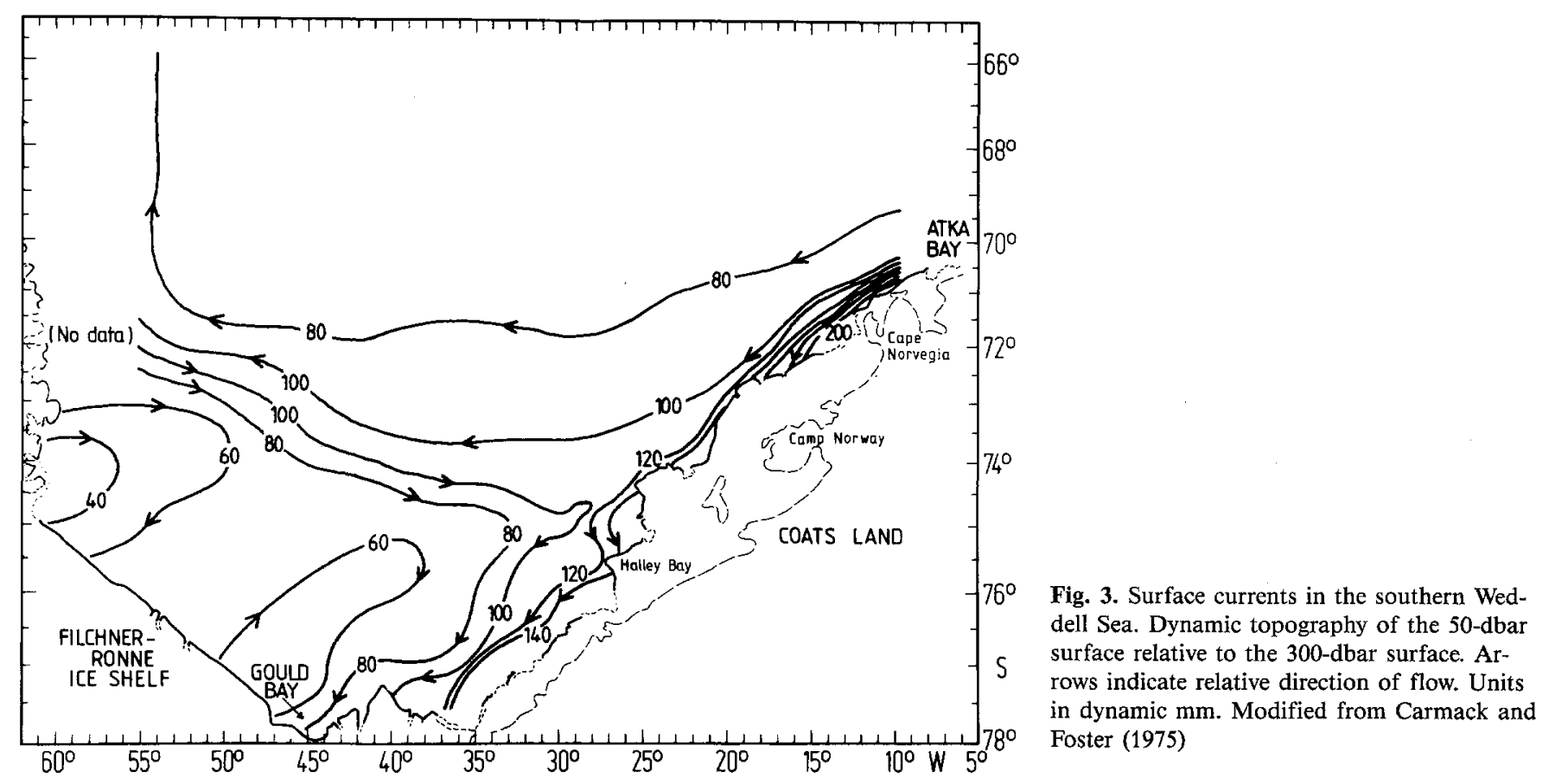

the eastern shelf is narrow and like the southern shelf interrupted by deep trenches, warmer water reaches up to the coast off Camp Norway and Halley Bay in a depth of more than $500 \mathrm{~m}$ (Fig. 2). Like the Eastwind Drift a coastal current flows in westerly direction, creating a divergence zone at approximately $27^{\circ} \mathrm{W}$, near Halley Bay (Gill 1973; Carmack and Foster 1977). Here the main component of the water masses follows the continental shelf slope to the north-west separating the cold Shelf Water from the Warm Deep Water. The other part of the coastal current continues as a coastal jet in a southwesterly direction to the southern shelf region (Fig. 3). Near Halley Bay cold Ice Shelf Water rises to the surface (Fig. 2), probably conditioned by seawards directed katabatic winds and the divergence zone in this region.

\section{Results}

A species list with mean abundances, frequencies of occurrence and percent occurrences in the three depth strata sampled is presented in Table 1. Mean abundances are calculated from positive hauls only and are given for the RMT 1 or the RMT 8 (\#). The frequency of occurrence $(\mathrm{P} \%)$ is given for both nets if available. Positive hauls are more numerous for the RMT 8, although most species abundances are higher in the RMT 1-samples.

\section{Number of Species}

The meso- and macrozooplankton of the Weddell Sea consisted of at least 110 species including larval stages of benthic and nektonic forms. On the southern shelf a total of 55 species occurred regularly, eight of them were larvae and juveniles of benthic species. Sixty-four species were found on the north-eastern shelf. The epipelagic zooplankton of the oceanic Weddell Sea consisted of 61 species, many of them were typical forms of the Eastwind Drift. Some new species were discovered. Of these, two gammaridean amphipods were meanwhile taxonomically described: Atylopsis procerus Andres 1986 and Cheirimedon solidus Andres 1986 (Andres 1986).

\section{Systematic Account}

Coelenterata. Among the coelenterates of the Weddell Sea siphonophores were by far the most abundant: Dimophyes arctica and Diphyes antarctica were present in all samples, Pyrostephos vanhöffeni was mainly found in coastal regions, Vogtia serrata only occurred in oceanic waters. Dimophyes arctica reached the largest densities with a mean of 85 ind. $/ 1000 \mathrm{~m}^{3}$. Regularly, but in low numbers the hydromedusae Calycopsis borchgrevinki and Botrynema sp. were found in the oceanic Weddell Sea. Scyphomedusae occurred sporadically. Except for Diphyes antarctica all species preferred the stratum between $200 \mathrm{~m}$ and $300 \mathrm{~m}$.

Gastropoda. Planktonic gastropods consisted of pteropods and larval lamellariids. The most abundant pteropod Limacina helicina was mainly collected in the upper stratum, especially in coastal waters. Its highest concentration was detected in the southern Weddell Sea $\left(2950 \mathrm{ind} . / 1000 \mathrm{~m}^{3}\right)$. The species made up $88 \%$ of all gastropods caught. A similar distribution pattern was found for the two echinospira forms of lamellariids. According to their subsequent benthic life they were caught chiefly in shallow coastal waters. The pteropods Clione limacina and Spongiobranchaea australis were present at 
Table 1. Zooplankton species sampled in the Weddell Sea in February and March 1983. Abundance values represent a mean of all positive oblique $0-300 \mathrm{~m}$ hauls. They are given for the RMT 1 or the RMT $8(\#)$. sd = standard deviation, $\mathrm{P}=$ frequency of occurrence. The species presence on the southern shelf $(\mathrm{S})$, on the north-eastern shelf $(\mathrm{N})$ and in oceanic waters $(\mathrm{O})$ is marked $(+)$. The vertical distribution of abundant species in the three depth strata is shown in percentages

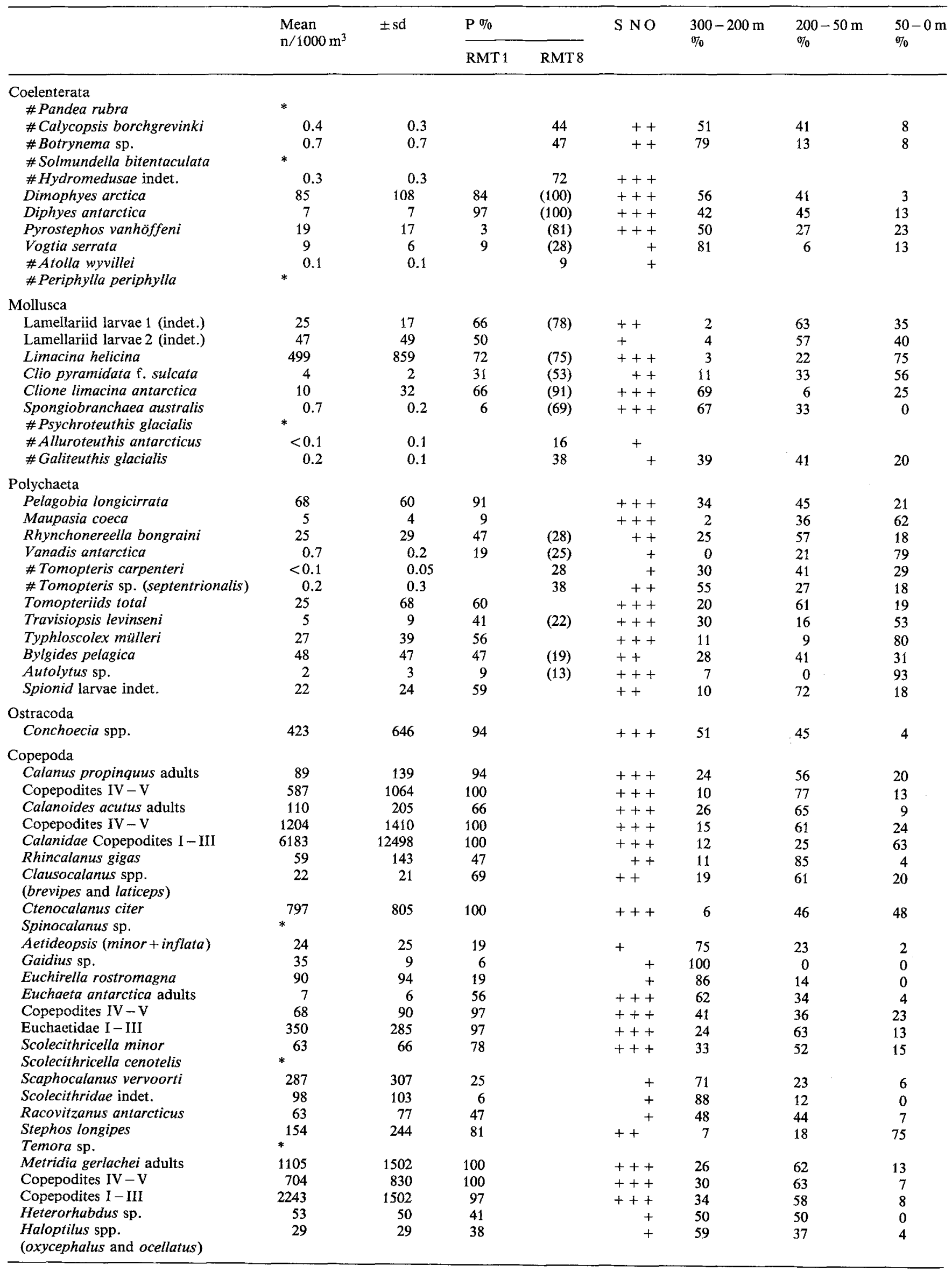


Table 1 (continued)

\begin{tabular}{|c|c|c|c|c|c|c|c|c|}
\hline & \multirow{2}{*}{$\begin{array}{l}\text { Mean } \\
\mathrm{n} / 1000 \mathrm{~m}^{3}\end{array}$} & \multirow[t]{2}{*}{ $\pm s d$} & \multicolumn{2}{|l|}{$\mathrm{P} \%$} & \multirow[t]{2}{*}{$\mathrm{SNO}$} & \multirow{2}{*}{$\begin{array}{l}300-200 \mathrm{~m} \\
\%\end{array}$} & \multirow{2}{*}{$\begin{array}{l}200-50 \mathrm{~m} \\
\%\end{array}$} & \multirow{2}{*}{$\begin{array}{l}50-0 \mathrm{~m} \\
\%\end{array}$} \\
\hline & & & RMT1 & RMT 8 & & & & \\
\hline Candacia sp. & * & & & & & & & \\
\hline Paralabidocera sp. & $*$ & & & & & & & \\
\hline Oithona spp. & 775 & 2405 & 88 & & $+t+$ & 8 & 6 & 86 \\
\hline Oncaea spp. & 837 & 2018 & 72 & & $++t$ & 14 & 77 & 8 \\
\hline Lubbockia sp. & $*$ & & & & & & & \\
\hline Harpacticoidea & 23 & 29 & 13 & & ++ & 26 & 14 & 60 \\
\hline \multicolumn{9}{|l|}{ Euphausiacea } \\
\hline \# Euphausia superba adult/juv. & 23 & 68 & $(50)$ & 81 & +++ & 7 & 9 & 84 \\
\hline E. superba larvae & 13 & 8 & 16 & & + & 24 & 74 & 2 \\
\hline \# Euphausia crystallorophias & 54 & 125 & $(62)$ & 72 & ++ & 45 & 34 & 21 \\
\hline E. crystallorophias larvae & 1927 & 3387 & 84 & & +++ & 4 & 14 & 82 \\
\hline Thysanoessa macrura adult/juv. & 8 & 13 & 72 & (75) & +++ & 14 & 27 & 59 \\
\hline$T$. macrura larvae & 183 & 417 & 47 & & ++ & 3 & 92 & 5 \\
\hline \multicolumn{9}{|l|}{ Decapoda } \\
\hline Notocrangon antarcticus & 2 & 2 & 63 & $(75)$ & ++ & 28 & 40 & 32 \\
\hline Chorismus antarcticus & 1 & 1 & 25 & (38) & ++ & 15 & 15 & 70 \\
\hline Acanthephyra pelagica & 7 & 17 & 25 & $(28)$ & + & 34 & 52 & 14 \\
\hline Hymenodora gracilis & 0.6 & 0.2 & 2 & (9) & + & 29 & 29 & 42 \\
\hline \multicolumn{9}{|l|}{ Mysidacea } \\
\hline $\begin{array}{l}\text { Antarctomysis spp. } \\
\text { \# Euchaetomera zurstrasseni }\end{array}$ & * $\quad 0.4$ & 0.4 & (13) & 19 & +++ & 90 & 10 & 0 \\
\hline \multicolumn{9}{|l|}{ Amphipoda } \\
\hline Allogaussia macrophthalma & 0.5 & 0.1 & 9 & & + & 50 & 25 & 25 \\
\hline \#Cheirimedon fougneri & $*$ & & & & & & & \\
\hline Cheirimedon solidus sp. n. & $*$ & & & & & & & \\
\hline \# Cyphocaris richardi & $*$ & & & & & & & \\
\hline Orchomene rossi & 2 & 2 & 53 & $(50)$ & ++ & 36 & 49 & 15 \\
\hline Orchomene plebs & 2 & 2 & 34 & (34) & ++ & 11 & 89 & 0 \\
\hline Orchomenella pinguides & $*$ & & & & & & & \\
\hline \#Orchomenella hiata & $*$ & & & & & & & \\
\hline \#Uristes gigas & $*$ & & & & & & & \\
\hline Epimeriella macronyx & 3 & 3 & 34 & $(41)$ & + & 26 & 63 & 0 \\
\hline \#Eusirus propeperdentatus & 2 & 2 & $(25)$ & 41 & + & 37 & 51 & 12 \\
\hline Eusirus antarcticus & $*$ & & & & & & & \\
\hline Eusirus microps & 0.5 & 0 & 9 & $(47)$ & ++ & 30 & 51 & 19 \\
\hline Atylopsis procerus sp. $\mathrm{n}$. & $*$ & & & & & & & \\
\hline \#Scina sp. & $*$ & & & & & & & \\
\hline Vibilia antarctica & 8 & 0 & 3 & (6) & + & 7 & 14 & 79 \\
\hline Cyllopus lucasii & 4 & 6 & 9 & (34) & +++ & 63 & 26 & 11 \\
\hline Cyllopus magellanicus & $*$ & & & & & & & \\
\hline \# Hyperia macrocephala & $<0.1$ & 0.4 & & 6 & ++ & & & \\
\hline \# Hyperia sp. & $*$ & & & & & & & \\
\hline Hyperiella dilatata & 4 & 9 & 59 & $(72)$ & +++ & 25 & 61 & 14 \\
\hline Hyperiella macronyx & 0.8 & 0.3 & 25 & (41) & +++ & 52 & 17 & 30 \\
\hline Hyperoche medusarum & 1 & 1 & 31 & $(66)$ & +++ & 22 & 47 & 31 \\
\hline Primno macropa & 59 & 71 & 41 & (41) & ++ & 20 & 53 & 27 \\
\hline \multicolumn{9}{|l|}{ Chaetognatha } \\
\hline \# Sagitta gazellae & 6 & 5 & & 100 & $+t+$ & 46 & 45 & 9 \\
\hline \#Sagitta marri & 0.8 & 0.8 & & 44 & ++ & 74 & 23 & 3 \\
\hline \# Sagitta maxima & $*$ & & & & & & & \\
\hline \# Eukrohnia hamata & 7 & 9 & & 97 & +++ & 46 & 44 & 10 \\
\hline \# Eukrohnia bathypelagica & 0.2 & 0.1 & & 34 & ++ & 59 & 18 & 23 \\
\hline Chaetognatha total & 405 & 529 & 100 & & +++ & 47 & 44 & 9 \\
\hline Tunicata & & & & & & & & \\
\hline Salpa thompsoni & 41 & 59 & 34 & (59) & +++ & 72 & 16 & 12 \\
\hline Vertebrata (fishlarvae) & & & & & & & & \\
\hline Pleuragramma antarcticum AG 0 & 12 & 13 & 75 & $(72)$ & ++ & 6 & 16 & 78 \\
\hline \# Trematomus spp. & 0.2 & 0.2 & & 28 & ++ & 9 & 6 & 85 \\
\hline \#Aethotaxis mitopteryx & 3 & 5 & & 25 & ++ & 6 & 17 & 77 \\
\hline \# Prionodraco evansii & 0.1 & 0.1 & & 19 & ++ & 23 & 6 & 71 \\
\hline \# Dacodraco hunteri & 0.2 & 0.1 & & 56 & ++ & 7 & 63 & 30 \\
\hline \#Pagetopsis sp. & 0.3 & 0.3 & & 53 & ++ & 26 & 48 & 26 \\
\hline \# Bathylagus antarcticus & $<0.1$ & 0.1 & & 31 & +++ & 46 & 23 & 31 \\
\hline \#Notolepis coatsi & 1 & 1 & & 38 & ++ & 78 & 15 & 7 \\
\hline \# Myctophidae & $<0.1$ & 0.1 & & 9 & + & 100 & 0 & 0 \\
\hline
\end{tabular}

* Species occurring only once or twice 
most stations, but low in numbers. Clio pyramidata mainly occurred in the oceanic Weddell Sea.

Cephalopoda. Few juvenile cephalopods of the species Psychroteuthis glacialis, Alluroteuthis antarcticus, and Galiteuthis glacialis were collected in the oceanic region, mostly in the deepest stratum of the surface water.

Polychaeta. Eleven polychaete species were found in the Weddell Sea, three of them were larvae of benthic forms restricted to the shelf stations. The meroplanktonic Bylgides pelagica was second in numbers of all polychaetes caught. Spionid larvae were also frequent. The most abundant polychaete $\left(\overline{\mathrm{x}}=68 \mathrm{ind} . / 1000 \mathrm{~m}^{3}\right)$ was the holoplanktonic species Pelagobia longicirrata, occurring at nearly all stations. Rhynchonereella bongraini and the tomopteriids were as frequent as Typhloscolex mülleri, all of them preferring the upper strata of the oceanic stations. Vanadis antarctica, a large species and a characteristic form of the oceanic plankton, was low in numbers. Maupasia coeca and Travisiopsis levinseni occurred with low abundances in all regions.

Ostracoda. Ostracods were not identified to species level. Conchoecia spp. was found in the entire area with highest abundances over deep water.

Copepoda. Copepods were highest in numbers of both species and individuals. In February and March 1983 the majority consisted of young stages (copepodites I-III) of Calanus propinquus and Calanoides acutus $(\overline{\mathrm{x}}=$ 6183 ind. $\left./ 1000 \mathrm{~m}^{3}\right)$, and Metridia gerlachei $(\overline{\mathrm{x}}=$ 2243 ind. $\left./ 1000 \mathrm{~m}^{3}\right)$. These common Antarctic species were numerous in the whole area. The young Calanidae especially concentrated off the northern coast. Cthenocalanus citer, Euchaeta antarctica and Scolecithricella minor were frequent species, too. Among the Euchaetidae the copepodites I-III were numerically dominant $\left(\overline{\mathrm{x}}=350\right.$ ind. $\left./ 1000 \mathrm{~m}^{3}\right)$. The genera Oithona and Oncaea were encountered in great numbers and probably represented several species: Oithona similis and Oithona frigida, and Oncaea curvata and Oncaea antarctica, respectively. They significantly preferred oceanic waters. The abundances of these small-sized species are likely to be underestimated since the young and very small stages are not caught quantitatively by the RMT 1 . Mainly in coastal waters Clausocalanus laticeps, Clausocalanus brevipes, Stephos longipes, and harpacticoids occurred. In the Eastwind Drift some species were frequent which hardly pass the coastal convergence. These were Haloptilus ocellatus, Haloptilus oxycephalus, Rhincalanus gigas, Euchirella rostromagna, Gaidius sp. Scaphocalanus vervoorti and Racovitzanus antarcticus. Higher concentrations in the upper $50 \mathrm{~m}$ of the water column were observed in the young Calanidae, in the species Stephos longipes, Ctenocalanus citer and Oithona spp.
Euphausiacea. Euphausiids were represented by three species: Euphausia superba, Euphausia crystallorophias and Thysanoessa macrura. The Antarctic krill, Euphausia superba, was present at almost all stations except on the southern shelf where only few positive samples were obtained. The adults and juveniles partly occurred in large numbers $\left(>100\right.$ ind. $\left./ 1000 \mathrm{~m}^{3}\right)$, but their mean density was only moderate $\left(\bar{x}=23\right.$ ind. $\left./ 1000 \mathrm{~m}^{3}\right)$. They preferred the waters off the north-eastern coast with maximum concentrations at the surface. Larvae were caught only sporadically. Euphausia crystallorophias was one of the key species in the pelagic shelf ecosystem. It represented more than $90 \%$ of the euphausiids caught by the RMT. The larvae living at the surface concentrated in the southern Weddell Sea. The maximum density was encountered over the Filchner Depression (15500 ind./ $1000 \mathrm{~m}^{3}$ ). All calyptopis and furcilia stages were found. On the southern shelf the calyptopis II stage dominated, in the northern coastal area the calyptopis III stage was most abundant. Few metanauplia were encountered in the southernmost part of the Weddell Sea. With moderate densities (Table 1) Thysanoessa macrura was the prevailing euphausiid in oceanic waters. The larvae preferred the northern coastal waters not penetrating into the southern Weddell Sea. The dominant larval stage was the first furcilia.

Decapoda. Decapods caught in low to moderate numbers $\left(<10\right.$ ind. $\left./ 1000 \mathrm{~m}^{3}\right)$ in the upper $300 \mathrm{~m}$ of the water column were larvae and juveniles of benthic and bathypelagic species. Notocrangon antarcticus and Chorismus antarcticus occurred in shelf waters. Acanthephyra pelagica and Hymenodora gracilis were found exclusively in oceanic waters.

Mysidacea. Mysids appeared sporadically in all regions. With the exception of Euchaetomera zurstrasseni which was detected only once in the northern Weddell Sea the specimen caught were larvae and juveniles of the genus Antarctomysis.

Amphipoda. Among the 24 amphipod species found in the Weddell Sea eleven hyperbenthic species appeared only once in the hauls (Table 1). Orchomene rossi, Orchomene plebs, Eusirus propeperdentatus and Epimeriella macronyx were the most abundant gammarids. They occurred regularly on the southern shelf. New species encountered were Cheirimedon solidus and Atylopsis procerus (Andres 1986). The hyperiid amphipods Hyperiella dilatata, Hyperiella macronyx, Hyperoche medusarum and Cyllopus lucasii were common and widely distributed in the whole area investigated. Primno macropa and Vibilia antarctica were restricted to the oceanic stations. Apart from Primno macropa all amphipod species occurred in low densities $\left(<10\right.$ ind. $\left./ 1000 \mathrm{~m}^{3}\right)$. With the exception of Eusirus propeperdentatus, which mostly appeared in the deepest layer of the surface water, the amphipods showed no clear preference for one of the strata. 
Chaetognatha. Chaetognaths were present with five species. Sagitta gazellae and Eukrohnia hamata were very common species in all RMT 8-samples, Sagitta marri and Eukrohnia bathypelagica appeared in oceanic waters, and Sagitta maxima was encountered only twice on the northeastern shelf. Most of the specimens caught by the RMT 1 were young and small individuals, probably Eukrohnia hamata, and were not identified to species level. With a mean abundance of 405 ind. $/ 1000 \mathrm{~m}^{3}$ this group was a main component of the zooplankton. Within the upper $300 \mathrm{~m}$ of the water column all species preferred the deepest stratum.

Tunicata. Salpa thompsoni was the only tunicate species found in our samples. With a mean abundance of 41 ind. $/ 1000 \mathrm{~m}^{3}$ it is not a rare species. Its distribution was very patchy, horizontally as well as vertically.

Vertebrata. Notothenioid post larvae contributed the major share of fish larvae caught with the RMT. The prevailing neritic species, Pleuragramma antarcticum, occurred in large numbers over innershelf trenches. The maximum concentration of its post larvae (age class 0 ) was found over the Filchner Depression within the upper layer (136 ind. $/ 1000 \mathrm{~m}^{3}$ ). The early life stages of Pleuragramma antarcticum made up $85 \%-98 \%$ of all fish larvae caught during the present survey (Hubold 1984). Other notothenioid larvae living on the shelf were Aethotaxis mitopteryx, Prionodraco evansii, Dacodraco hunteri, Pagetopsis sp. and Trematomus spp. The bathylagid Bathylagus antarcticus occurred sporadically in both oceanic and shelf waters. Only in oceanic waters were found larval stages of the paralepidid Notolepis coatsi and myctophids.

In summary, apart from the abundant species, the following forms were characteristic for the shelf regions: Pyrostephos vanhöffeni, Euphausia crystallorophias, Clausocalanus laticeps, Clausocalanus brevipes, Stephos longipes and Pleuragramma antarcticum. Limacina helicina was not restricted to the coastal regions, but represented a main component of the southern shelf plankton. Meroplanktonic forms like the larvae of spionids and lamellariids were typical as many species of the epibenthos (Epimeriella macronyx, Eusirus propeperdentatus, Eusirus microps, Notocrangon antarcticus, Chorismus antarcticus, Orchomene plebs and Orchomene rossi) and the notothenioid post larvae. Within the coastal waters some species show significantly lower densities south of a divergence zone, near Halley Bay (e.g., Thysanoessa macrura). The oceanic water masses are separated from the coastal shelf water by a continentclose convergence coinciding with the southernmost distribution of many species which are inhabitants of the Warm Deep Water of the Eastwind Drift: Calycopsis borchgrewinki, Vogtia serrata, Atolla wyvillei, Clio pyramidata, Galiteuthis glacialis, Vanadis antarctica, Tomopteris carpenteri, Gaidius sp., Euchirella rostromagna, Racovitzanus antarcticus, Heterorhabdus sp.,

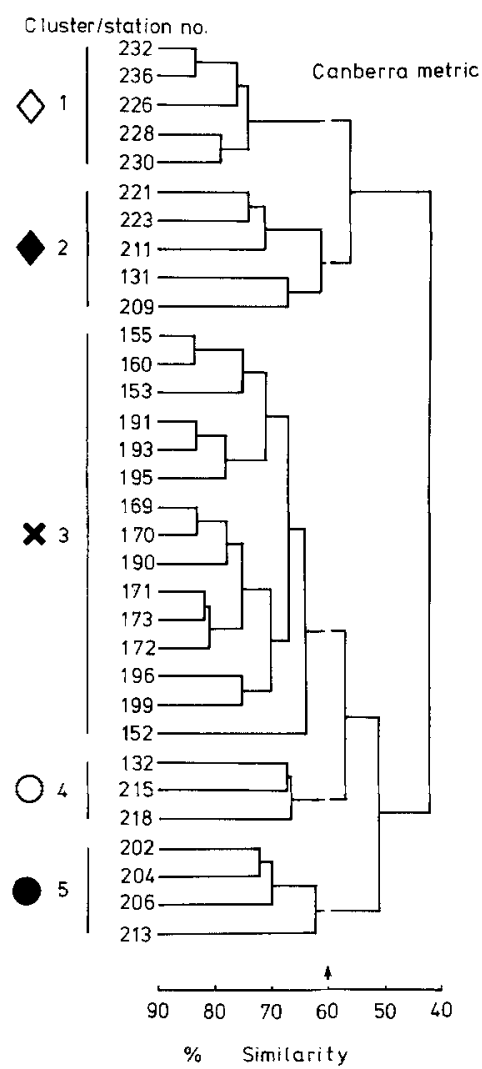

Fig. 4. Dendrogram of cluster analysis (Canberra-metric, complete linkage). Symbols are used in Fig. 5

Haloptilus ocellatus, Haloptilus oxycephalus, Acanthephyra pelagica, Hymenodora gracilis, Vibilia propinqua, Primno macropa and the larvae of myctophids.

\section{Community Analysis}

The analysis of zooplankton communities was carried out by cluster analysis. The result is shown in a dendrogram (Fig. 4), where the ordinate presents the station groupings and the abscissa a similarity degree. Regarding a similarity degree of $60 \%$ the dendrogram shows five groups of stations (cluster 1 to 5). On a lower level, it clearly separates oceanic (cluster 1 and 2) and neritic fauna (cluster 3 to 5). The stations of the northern Weddell Sea (cluster 1) differ little from those located off the coast over deep water (cluster 2). Cluster 3 represents the southern shelf stations. The north-eastern shelf stations are separated into two sub-groups (cluster 4 and 5). Cluster 4 consists of three shallow water stations close to the ice shelf. They show more similarity to the southern shelf stations than those of cluster 5, which are influenced by oceanic waters. Although heterogeneous, the stations of cluster 4 and 5 are lumped together as a shelf community defined by both neritic and oceanic features.

From these results three distinct communities can be derived: the Southern Shelf Community, the Northeastern Shelf Community, and the Oceanic Community. 


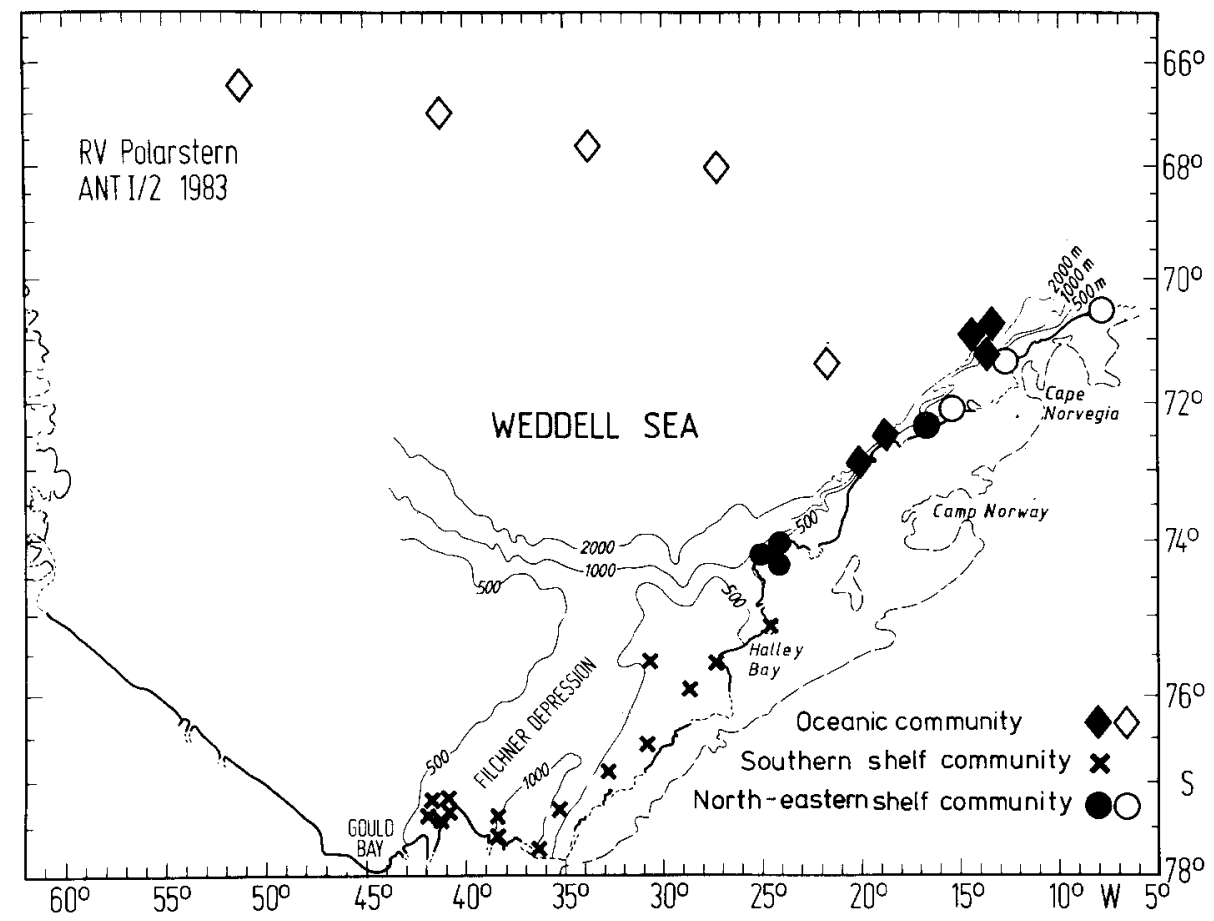

Fig. 5. Zooplankton communities of the Weddell Sea. Geographical extension as revealed by cluster analysis (see Fig. 4)
According to this separation the geographical grouping of the stations is shown in Fig. 5.

\section{Community Structure}

The occurrence of the zooplankton species in each community is indicated in Table 1 ( $\mathrm{S}=$ Southern Shelf Community, $\mathrm{N}=$ North-eastern Shelf Community, and $\mathrm{O}=$ Oceanic Community). The percent composition of the species and the different feeding types in the three communities are shown in Fig. 6. The dimensions of the blocks represent a mean of all individuals caught. It becomes obvious that the majority of each community consists of few species only, with quite different abundances.

The Southern Shelf Community has lowest abundances with a mean of 9247 ind. $/ 1000 \mathrm{~m}^{3}$. Larval stages of Euphausia crystallorophias (29.7\%) are dominant in numbers, followed by Metridia gerlachei (29.1\%). Calanus propinquus and Calanoides acutus (12.5\%), Limacina helicina $(8.2 \%)$ and Ctenocalanus citer $(5.1 \%)$ are important components, too. The portion of Euchaetidae, ostracods, chaetognaths, Oithona spp. and Oncaea spp. is small. The filter feeders are dominating $(57.3 \%)$, omnivores contribute $34.6 \%$, carnivores only $8.1 \%$.

The North-eastern Shelf Community has abundances three times higher $\left(\bar{x}=31107\right.$ larvae $\left./ 1000 \mathrm{~m}^{3}\right)$ than the southern one, consisting mainly of young copepodites of Calanus propinquus and Calanoides acutus $(60.9 \%)$. The high portion of the Calanidae highly affects the structure of the zooplankton community. Although abundant with a mean of $1112 \mathrm{ind} . / 1000 \mathrm{~m}^{3}$ the larvae of Euphausia crystallorophias only amount to $3.6 \%$ in the North- eastern Shelf Community whereas in the Southern Shelf Community 2748 ind. $/ 1000 \mathrm{~m}^{3}$ represent a much higher percentage of $29.7 \%$. The same applies to Metridia gerlachei, which is a relatively small component $(13.9 \%)$ of this community. Although inhabited by 64 species, only five constitute more than $95 \%$ of all individuals in this community. The prevailing feeding type is the fine-filter feeder contributing $64.5 \%$ whereas coarse-filter feeders form $17 \%$ and omnivores $16 \%$. Carnivores are scarce with a portion of only $2.5 \%$.

The Oceanic Community is dominated numerically again by the Calanidae (35.5\%), but in contrast to the North-eastern Shelf Community significantly more species occur in larger numbers. Several species contribute to the mean abundance of 22968 ind. $/ 1000 \mathrm{~m}^{3}$, i.e., Metridia gerlachei (24.6\%), Oithona spp. $(8.2 \%)$ and Oncaea spp. (8.1\%), Ctenocalanus citer $(4.5 \%)$, chaetognaths $(4.5 \%)$ and ostracods $(3.8 \%)$. The large quantities of young copepodites were found over the continental slope and the deep trench off Camp Norway (cluster 2), but not in the open Weddell Sea. Furthermore, Thysanoessa macrura, Scaphocalanus vervoorti, Rhincalanus gigas and Dimophyes arctica are abundant components of this community. Again dominated by filter feeders $(43.8 \%)$, omnivores $(32.2 \%)$ and carnivores $(24 \%)$ form substantial portions of the Oceanic Community.

\section{Discussion}

\section{Number of Species}

A number of 110 zooplankton species found in the Weddell Sea is a relatively low quantity compared to the diver- 


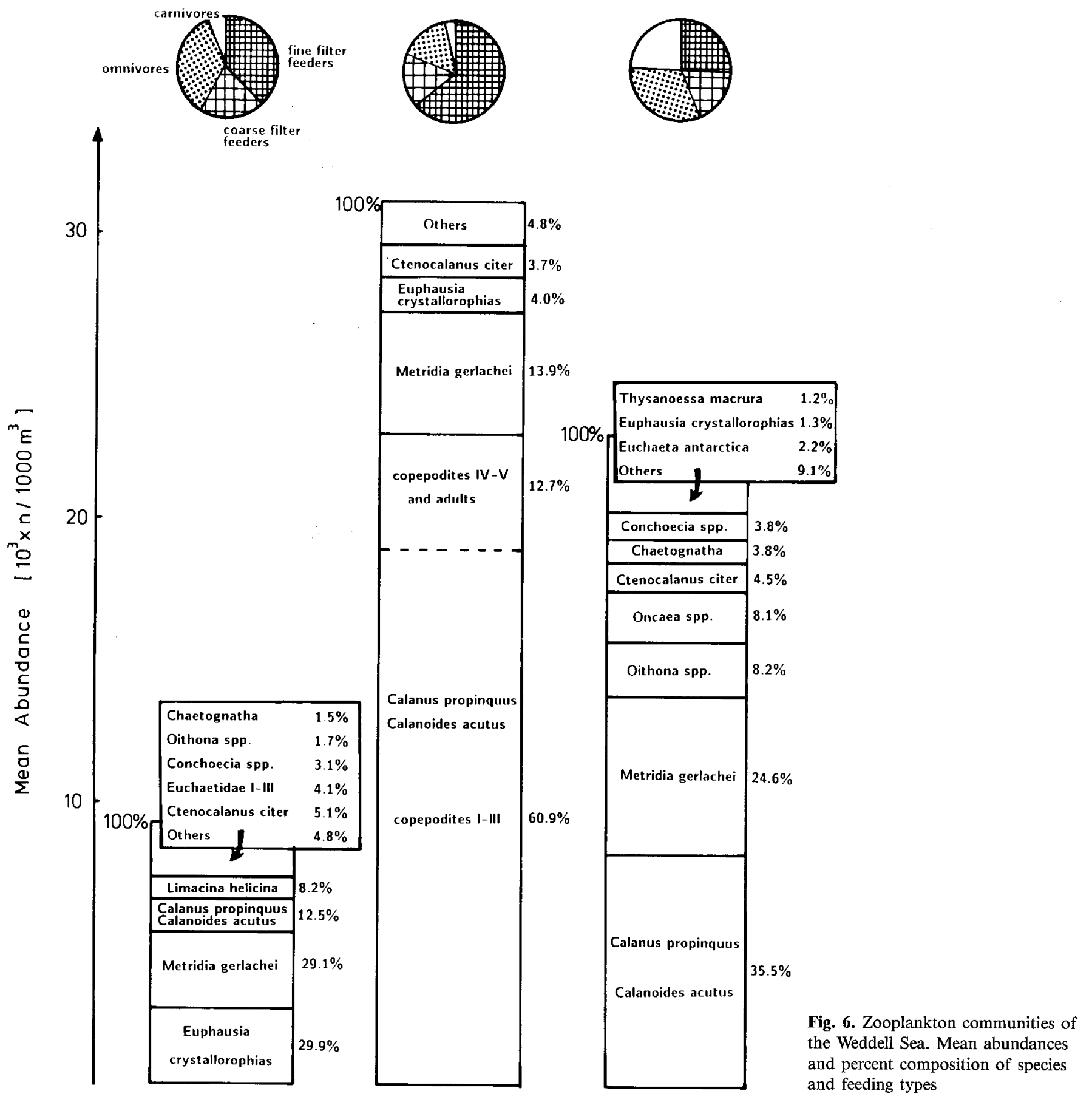

sity of warm water meso- and macrozooplankton. For example, Deevey and Brook (1977) encountered 326 copepod species in the Sargasso Sea. However, the number of species should always be examined carefully according to haul depth, type of sampling gear and time of sampling. The present investigation has been carried out during five weeks of austral summer. It only considers samples of the surface waters, whereas Deevey and Brook (1977) have sampled down to $2000 \mathrm{~m}$ over a period of three years. In the upper $150 \mathrm{~m}$ of the Nova Scotian Shelf and its slope region Sameoto (1984) found 64 zooplankton species including ichthyoplankton. With regard to depth and time of sampling (late summer) his investigation is more comparable to our study.

Up to now comprehensive zooplankton studies in shelf waters of the Southern Ocean analyzing species composition were lacking. Therefore, species numbers can only be compared to those other authors found in offshore regions of the Southern Ocean, mostly in surface waters at the Antarctic Peninsula. For example, 
Montú and Oliveira (1986) analyzed the trophic relationships of the zooplankton community near Elephant Island and found 34 macroplankton species during two Brazilian expeditions. Jazdzewski et al. (1982) sampled zooplankton in Bransfield Strait and southern Drake Passage and recorded a total number of about 70 taxonomic groups of various levels. In the Croker Passage which is surrounded by land masses the zooplankton community of the upper $1000 \mathrm{~m}$ consisted of 106 species (Hopkins 1985a). However, many of the 64 copepod species occurring there are meso-bathypelagic and are absent in the surface water of the Weddell Sea. Consequently Hopkins (1985a) did not find neritic species, like Euphausia crystallorophias, and meroplanktonic larvae, which were abundant in the coastal Weddell Sea. In Bransfield Strait and Drake Passage Zmijewska (1983) encountered 34 copepod species in the upper $200 \mathrm{~m}$, but only 18 in the high-Antarctic shelf waters of the Prydz Bay (Zmijewska 1985). Similar ratios are observed in the Weddell Sea, where species numbers of coelenterates, copepods and chaetognaths conspicuously decrease from the northern oceanic region to the eastern and southern shelf waters. On the other hand the shelf plankton contains many larvae and juveniles of benthic animals, which again increases the species diversity in shallow coastal waters.

\section{Distribution and Abundance}

Coelenterata. Hydromedusae are not very numerous in the Antarctic Ocean. Calycopsis borchgrevinki has a circumpolar distribution (Baker 1954), but according to Kramp (1959) it is restricted to the Atlantic sector of the Southern Ocean. We found the species in small numbers in the northern Weddell Sea, mainly below $200 \mathrm{~m}$ in the Warm Deep Water of the Eastwind Drift. A similar distribution pattern was obtained for Botrynema sp. (probably Botrynema brucei) which is a bathypelagic form of the Warm Deep Water (Kramp 1968).

The siphonophores Dimophyes arctica and Diphyes antarctica were widely distributed all over the Weddell Sea. Both are predominant macroplankton species of the Oceanic Community, with a mean abundance of 157 and 13 ind. $/ 1000 \mathrm{~m}^{3}$, respectively. According to Hopkins (1985a) they prefer the depth strata between 200 and $600 \mathrm{~m}$. Diphyes antarctica is endemic in the Southern Ocean (Moser 1925), while Dimophyes arctica occurs in all oceans at temperatures between $-1.1^{\circ} \mathrm{C}$ and $13.3^{\circ} \mathrm{C}$ (Moser 1925). Pyrostephos vanhöffeni was caught in coastal waters of the Weddell Sea, which coincides with records of Moser (1925) and Totton and Bargmann (1965) who found the species close to the continent and under the ice of the Ross Sea. Vogtia serrata, a bathypelagic cosmopolitan (Moser 1925), occurred in the deepest stratum only, bound to the Warm Deep Water of the Eastwind Drift.
Gastropoda. Echinospira forms of gastropod larvae are well known in temperate seas (Lebour 1935), but were recorded for the first time in Antarctic waters during our survey. Pelagic larvae of prosobranchs are an exception in polar seas (Picken 1980). The two species we found belong to the lamellariidae and occurred in the upper $200 \mathrm{~m}$ of the shelf waters, mainly in the south. The endemic pteropod Limacina helicina lives in the upper stratum feeding on phytoplankton (Gilmer 1974) and showed largest concentrations in the Gould Bay. High abundances in the southern Weddell Sea may be due to an accumulation by the coastal current, which is strongest at the surface. Although occurring mainly in shelf waters the species is not exclusively neritic, but develops in masses in areas of phytoplankton blooms (Witek et al. 1985). According to Sakshaug and HolmHansen (1984) the bloom does not start before February in the high-Antarctic waters. Actually, during February 1983 , primary production was very high in the southern Weddell Sea, reaching $1670 \mathrm{mg} \mathrm{C} / \mathrm{m}^{2} /$ day (Von Bröckel 1985). Another thecosomatous pteropod, Clio pyramidata, was mainly found in the northern Weddell Sea and represented a characteristic species of the Oceanic Community. Chen (1968) recorded very high numbers of up to 10000 ind. $/ 1000 \mathrm{~m}^{3}$ in the South Sandwich Trench, but the abundance in the Weddell Sea was much lower $\left(<4\right.$ ind. $\left./ 1000 \mathrm{~m}^{3}\right)$. The Gymnosomatae Clione limacina and Spongiobranchaea australis occurred in small numbers in the whole area investigated. In the Croker Passage their abundances are lower than 10 ind. $/ 1000 \mathrm{~m}^{3}$ (Hopkins 1985 a). Clione limacina is known as a predator on Limacinidae (Conover and Lalli 1972).

Cephalopoda. The knowledge on distribution and abundance of Antarctic cephalopods is poor. However, a great number of cephalopod beaks in stomachs of Weddell seals and emperor penguins lead to the assumption that there are high concentrations of squids in the Weddell Sea (Plötz 1986, and personal communication). Early life stages of the cranchiid Galiteuthis glacialis contributed the major share of a relatively high number of squids caught by the RMT 8 . They appeared regularly in oceanic waters. Recently, Rodhouse and Clarke (1986) report on the occurrence of Galiteuthis glacialis south of the Antarctic Polar Front, and according to Voss (1980) the species has a circumpolar distribution.

Polychaeta. Among the polychaetes of the Weddell Sea the cosmopolitan species Pelagobia longicirrata (Hartman 1964) is the most frequent. Its dominance in Antarctic waters is often reported (Tebble 1968; Orensanz et al. 1974; Støp-Bowitz 1977), even in the coastal areas of the Weddell Sea (Augener 1929). In summer, the species lives at the surface feeding on phytoplankton (Hopkins $1985 \mathrm{~b})$. In lower latitudes it is inhabiting deeper layers (Tebble 1960). During an Argentine zooplankton survey from South America to the northern Weddell Sea, highest 
abundances were found in the Drake Passage (Orensanz et al. 1974). Maupasia coeca was rarely caught possibly due to its distribution extending to $750 \mathrm{~m}$ depth (O'Sullivan 1982). The alciopids Rhynchonereella bongraini and Vanadis antarctica are endemic polychaetes. They were missing in the southern Weddell Sea. According to Augener (1929) Rhynchonereella bongraini occurs in the northern Weddell Sea. In the Ross Sea the species is abundant (Støp-Bowitz 1977). Vanadis antarctica has very low abundances. Its circumpolar distribution reaches as far north as the Antarctic Convergence and it is found down to $2000 \mathrm{~m}$ (Hartman 1964). Tomopteris carpenteri and Tomopteris septentrionalis were frequently encountered in the northern Weddell Sea. Augener (1929) recorded a third species, Tomopteris planktonis, which did not appear in our samples. Except for Tomopteris carpenteri the tomopteriids are cosmopolitans like the rare species Thyphloscolex mülleri and Travisiopsis levinseni (Hartman 1964). Their vertical distributions reach down to $3000 \mathrm{~m}$ and $2200 \mathrm{~m}$, respectively (O'Sullivan 1982), where they inhabit the Warm Deep Water (Hardy and Gunther 1936). In contrast, in the Weddell Sea both species were concentrated in the upper $50 \mathrm{~m}$ with Thyphloscolex mülleri being relatively abundant $\left(\bar{x}=27\right.$ ind. $\left./ 1000 \mathrm{~m}^{3}\right)$. The discrepancy might be explained by seasonal differences in the vertical distribution or ontogenetic migrations. The occurrence of larvae and juveniles of benthic polychaetes like Polynoidae, Syllidae and Spionidae in shelf areas is known from earlier reports (Ehlers 1913; Augener 1929). In the Weddell Sea Bylgides pelagica was most abundant. According to Hartman (1964) the species is identical with Herdmanella gracilis which Augener (1929) described as the most frequent polychaete of the Weddell Sea. The spionid larvae were also encountered regularly on the shelf. They are described in detail by Ehlers (1913) who found them in "swarms" close to the continent.

Ostracoda. Ostracods have significantly higher abundances in the oceanic than in the shallow waters of the Weddell Sea. Hardy and Gunther (1936) described eight species of the genus Conchoecia occurring over the deep waters around South Georgia. In the Croker Passage Hopkins (1985a) found seven species down to $1000 \mathrm{~m}$, dominated by Conchoecia belgicae, Conchoecia isocheira and Conchoecia hettacra $\left(114,79\right.$, and 13 ind. $/ 1000 \mathrm{~m}^{3}$, respectively), which preferred the deeper layers. However, the ostracod abundance in the surface water of the Weddell Sea amounts to 423 ind. $/ 1000 \mathrm{~m}^{3}$.

Copepoda. Distribution patterns of copepods were studied in coastal areas of the Ross Sea (Farran 1929), Prydz Bay (Zmijewska 1983) and Weddell Sea (Kaczmaruk 1983). Among the 29 copepod species caught in the upper $300 \mathrm{~m}$ of the Weddell Sea the large-sized species Calanus propinquus, Calanoides acutus and Metridia gerlachei were very numerous and made up $80 \%$ of all copepods caught. In the Prydz Bay during February 1969 , they also were the most numerous copepods caught (Zmijewska 1983). However, Kaczmaruk (1983) described the copepod fauna of the Weddell Sea during February and March 1980 as being poor. Abundances were low and diversity decreased from north to south. Either one of the small species Ctenocalanus vanus (= Ctenocalanus citer), Oithona sp. or the young copepodites of the Calanidae were dominant, whereas older stages of Calanus propinquus, Calanoides acutus and Euchaeta antarctica were scarce. The rareness of these large species can probably be explained by avoidance of the small vertical net Kaczmaruk used. From literature many informations are available on the distribution of Calanus propinquus, Calanoides acutus and Rhincalanus gigas. They are very abundant species in the West- and Eastwind Drift. Voronina $(1970,1972 a, b)$ concluded that these three species occur in the surface waters successively from north to south. Calanoides acutus is the earliest in austral spring ascending from deep layers to the surface where spawning takes place. The young copepodites live in the uppermost stratum and make up the majority of the population. With progressing development they migrate somewhat deeper but remain in surface waters during the summer. In autumn the copepodites IV-V descend to deeper layers to overwinter. The development of Calanus propinquus starts later in the season, and Rhincalanus gigas migrates late to surface waters. Hence, it depends on time and latitude which species is found to be dominant. That explains the different abundances given by Farran (1929), Ottestad (1932, 1936) and Vervoort (1951). Calanoides acutus is known to penetrate southernmost waters, whereas Calanus propinquus prefers the waters of the Westwind Drift. The main distribution of Rhincalanus gigas is sub-Antarctic, spawning takes place only in waters with surface temperatures above $0^{\circ} \mathrm{C}$ (Ottestad 1932). In the northern Weddell Sea Ommanney (1936) and Steuer (1937) found no summer generation. This is in accordance with the distribution of Rhincalanus gigas in the present study. No copepodites I-III were encountered, older stages were scarce and mainly found in the Warm Deep Water. Unfortunately, we cannot prove whether the ontogenesis of Calanoides acutus is different from that of Calanus propinquus because young stages were not separated. Regarding the copepodites IV-VI only, numbers of Calanoides acutus are double the amount of Calanus propinquus. The high quantities of young copepodites in the North-eastern Shelf Community are difficult to explain. Presuming that spawning took place in the northern shelf areas, a sufficient food supply and accumulation by hydrographic features might be responsible for the local maintenance of the summer generation. According to Vladimirskaya (1978) the species have significantly higher numbers in the Eastwind Drift than in the Weddell Sea. The vertical distribution of the Calanidae is typical for the summer months (Voronina 1972b). All stages live in the surface layer, the youngest in the uppermost stratum. 
The third abundant species, Metridia gerlachei, lives below the thermocline and is very numerous down to $1000 \mathrm{~m}$ (Ottestad 1932). In the Eastwind Drift abundances are lower than those of the Calanidae, but in the Weddell Sea Metridia gerlachei outnumbers Calanoides acutus (Ottestad 1936). Its distribution reaches from $60^{\circ} \mathrm{S}$ to the continent with dense concentrations close to the ice edge (Farran 1929). In coastal waters off the Antarctic Peninsula Metridia gerlachei is more numerous than in adjacent oceanic waters (Jazdzewski et al. 1982; Schnack et al. 1985), and in the Croker Passage it is the dominant zooplankton species, being first in biomass and second in numbers (Hopkins 1985a). The species is omnivorous and undertakes diurnal vertical migrations (Vervoort 1965). In the present study the absolute numbers of Metridia gerlachei are highest in oceanic waters, but the species represents a substantial portion in the Southern Shelf Community.

Apart from these copepods only Ctenocalanus citer, Oithona spp. and Oncaea spp. were abundant species. Ctenocalanus citer was relatively numerous contributing $5.2 \%$ of all copepods caught, while Kaczmaruk (1983) even recorded a portion of $20 \%$ at most stations. She found highest abundances off the northern coast corresponding to our results. This herbivorous species lives epipelagically (Vervoort 1951). The cyclopoid copepods Oithona spp. and Oncaea spp. can dominate in numbers: In the upper $1000 \mathrm{~m}$ of the Croker Passage Oncaea curvata was the most numerous zooplankton species, Oncaea antarctica was third in numbers (Hopkins 1985 a). In the southern Weddell Sea Oithona spp. dominated all stations west of the Filchner Depression (Kaczmaruk 1983), and at the Antarctic Peninsula both genera together have a portion ranging from $40 \%$ to $80 \%$ (Schnack et al. 1985 ). In our study they only reach about $4 \%$ each. These discrepancies can be explained by the smaller mesh sizes $(162-253 \mu \mathrm{m})$ other authors used. As mentioned above, young individuals were not caught quantitatively by the RMT 1. Except for Oithona similis, species of both genera mainly live below $300 \mathrm{~m}$ (Hopkins 1985a), which is another reason for the lower abundances of the present study. The genus Oithona is probably represented by two species, Oithona similis and Oithona frigida, the latter living mainly between 400 and $800 \mathrm{~m}$ (Hopkins 1985a). Both are cold-water species (Rosendorn 1927). Oithona frigida is endemic and often encountered at the ice edge (Farran 1929). Oncaea curvata is described as typical Antarctic species which occurs only south of $60^{\circ} \mathrm{S}$ and is frequent in the ice zone (Wolfenden 1911; Farran 1929). Compared to other studies abundances in the oceanic Weddell Sea are smaller by one order of magnitude.

In the remaining $5.5 \%$ of all copepods, the Euchaetidae were highest in numbers. Euchaeta antarctica numerously occurs down to $1000 \mathrm{~m}$ (Hopkins 1985 a) and is a typical inhabitant of the Warm Deep Water (Vervoort 1965). Accordingly, adults and copepodites IV-V were mainly found in the deeper strata of the northern Weddell Sea, but young stages are most numerous in the south. As inhabitants of surface waters between 50 and $200 \mathrm{~m}$ they were probably carried southwards by the coastal current. While other authors described Clausocalanus laticeps and Clausocalanus brevipes in the Eastand Westwind Drift (Frost and Fleminger 1968; Nakamura et al. 1982), we found both species in coastal waters only. Of the Aeteidae four rare species occurred in the Weddell Sea: Euchirella rostromagna and Gaidius sp. were restricted to the oceanic waters, likely because they prefer the Warm Deep Water (Vervoort 1965). Apetideopsis inflata and Aetideopsis minor, reported from layers below $400 \mathrm{~m}$ (Park 1978), were probably carried with the Deep Water as far south as the Filchner Depression. Stephos longipes is a common Antarctic copepod (Wolfenden 1911) and was present in the Weddell Sea at all coastal stations, mainly in the uppermost stratum. An identical distribution pattern was found by Kaczmaruk (1983). In contrast, during April 1983 Hopkins (1985a) observed maximal densities between 400 and $600 \mathrm{~m}$ assuming the beginning winter descent. Apart from Scolecithricella minor, the Scolecithridae clearly prefer oceanic waters. Racovitzanus antarcticus and Scaphocalanus vervoorti are restricted to the Warm Deep Water (Vervoort 1965). Although known from bathypelagic layers (Park 1982) Scaphocalanus vervoorti was encountered in relatively high numbers in surface waters of the northern Weddell Sea. Scolecithricella minor was present at nearly all stations, whereas Kaczmaruk (1983) did not record this species. The Augaptilidae and Heterorhabdidae do not penetrate into the shelf waters. Haloptilus ocellatus, Haloptilus oxycephalus and Heterorhabdus sp. mainly inhabit the Westwind Drift and are transported into the northern Weddell Sea with the Warm Deep Water (Vervoort 1965). With the exception of Microcalanus pygmaeus, which can reach dominant numbers in the waters off the Antarctic Peninsula (Schnack et al. 1985), all copepod species abundant in the Eastwind Drift are also numerous in the inner Weddell Sea.

Euphausiacea. Among the euphausiids Euphausia crystallorophias is the dominant species in shallow waters ( $<400 \mathrm{~m}$ depth) of the Weddell Sea (Fevolden 1980; Siegel 1982). It is known as a key species of high-Antarctic shelf regions (Kittel and Presler 1980; Piatkowski 1985 a). Replacing Euphausia superba in shallow waters it is a staple food of typical krill consumers (Mackintosh 1970). The larvae of Euphausia crystallorophias feed on phytoplankton, older stages can also cope with detritus and benthic diatoms (Kittel and Ligowski 1980). The larvae were found in the uppermost stratum, juveniles and adults in deeper layers, coinciding with a change of main feeding type during ontogenesis. The adults occurred on shelf stations only, while larvae were numerous in coastal waters, even over deep trenches. Highest abundances were found in the Filchner Depression and Gould Bay. They form a main component $(\mathbf{2 9 . 7 \% )})$ of the Southern Shelf Community. The larvae of the northern shelf areas are further developed than those south of the Halley 
divergence. The delayed polynya formation in the south causes a retarded onset of spring conditions, which is probably the reason for the species not to spawn here before January. Similar conclusions are described by Hempel and Hempel (1982) who encountered the earliest larval stages in the south. In shelf areas off the Antarctic Peninsula also Euphausia superba, the Antarctic krill, occurs in large swarms, but the swarms are always spatially separated from those of Euphausia crystallorophias (Kittel 1980). In the Weddell Sea Euphausia superba occurred in large numbers only in the north-eastern region. High concentrations of krill are often observed in areas favouring phytoplankton blooms like the ice-edge zone (e.g., Ruud 1932; Tranter 1982; personal observations). In spite of high primary production in the southern Weddell Sea (Von Bröckel 1985), Euphausia superba is far less successful than Euphausia crystallorophias. Possibly, it lives underneath the ice of the Weddell Sea raking off diatoms from the underside (Hempel 1987). In contrast to other studies (e.g., Fevolden 1980) we found only few larvae. In the Weddell Sea, Euphausia superba does not spawn before February (Hempel and Hempel 1982). Gravid or spent females are found in the shallow Atka Bay, but not in the inner Weddell Sea (Siegel 1982), and the encountered larvae stem probably from higher latitudes. Thysanoessa macrura is the second dominating euphausiid species in the Southern Ocean (Mackintosh 1934). In February and March 1983 the species was an abundant component of the oceanic Weddell Sea. To avoid competition with Euphausia superba the species spawns earlier in the season (Makarov 1979). Early larval stages occur from September to December depending on latitude (Makarov 1979). In the Weddell Sea the predominating furciliae $(>90 \%)$ indicate the ongoing season. The larvae do not penetrate the southern shelf, which is in good accordance with results of previous investigations (Fevolden 1980; Hempel and Hempel 1982; Siegel 1982).

Decapoda. Pelagic larvae of benthic decapods were found in the shelf waters: Notocrangon antarcticus and Chorismus antarcticus are endemic and circumpolarly distributed (Yaldwyn 1965). Chorismus antarcticus is most abundant in shallow waters down to $300 \mathrm{~m}$, while Notocrangon antarcticus prefers depths between 300 and $600 \mathrm{~m}$ (Kirkwood 1983). Probably due to the deep shelf in the inner Weddell Sea we found mainly larvae of Notocrangon antarcticus. The bathypelagic species Acanthephyra pelagica and Hymenodora gracilis occurred over great depths in the northern Weddell Sea. They are also known from the Northern Hemisphere. Acanthephyra pelagica lives in deeper layers down to $4900 \mathrm{~m}$, and Hymenodora gracilis is frequent below $3500 \mathrm{~m}$, but its vertical distribution even extends to surface waters (Kirkwood 1983).

Mysidacea. The mostly juvenile mysids we caught belong to the genus Antarctomysis with the species Antarc- tomysis maxima and Antarctomysis ohlini. Both are endemic forms of the Antarctic shelf (Birstein and Chindonova 1962; Ward 1985).

Amphipoda. The gammaridean amphipods Orchomene plebs, Orchomene rossi, Epimeriella macronyx and Eusirus propeperdentatus were numerous in the southern Weddell Sea, even over the deep Filchner Depression, but nearly absent on the shallower northern shelf. Orchomene plebs and Orchomene rossi are benthic species, but commonly young individuals intrude into the pelagic zone (Andres 1978). Orchomene plebs spawns in shallow waters, the eggs develop during winter and hatching takes place in spring. In summer the juveniles occur on the shelf, whereas the adults live as deep as $760 \mathrm{~m}$ (RakusaSuszczewski 1982). We suppose that the animals of the southern shelf are younger than in the northern areas due to the later onset of spring. On the northern shelf they already live close to the bottom. This correlation between vertical distribution and ontogenesis may also explain the distribution of Eusirus propeperdentatus, Eusirus microps and Epimeriella macronyx, of which we found juveniles only. Eusirus propeperdentatus is the dominant gammarid in the mesopelagic environment of the Scotia Sea (Andres 1978). In the present study it was a typical form of the southern shelf fauna. The distribution of Allogaussia macrophthalma extends north to sub-Antarctic waters (Birstein and Vinogradov 1962). It was only found on a few oceanic stations.

Primno macropa was the most abundant hyperiid amphipod frequently encountered in the Eastwind Drift. It avoids the cold coastal shelf water (Bowman 1985). Hyperiella dilatata, Hyperiella macronyx, Hyperoche medusarum and Cyllopus lucasii were well-distributed over the entire area showing moderate numbers, which agrees to earlier records from the Weddell Sea (Hempel et al. 1983; Weigmann-Haass 1983). Although Themisto gaudichaudii is the dominant hyperiid of the Westwind Drift (Kane 1966), the species was not encountered in our samples. It is a prevailing component off the Antarctic Peninsula, but missing where Weddell Sea Water intrudes into the Bransfield Strait (Piatkowski 1985a).

Chaetognatha. Chaetognath species are uniformly distributed in the Southern Ocean (Mackintosh 1934). They have a circumpolar distribution (Alvariño 1983a,b) and are major components of the zooplankton in the Westwind Drift (David 1958). Sagitta gazellae and Eukrohnia hamata are dominating species (Hagen 1985) which is confirmed by the present results. Sagitta marri and Eukrohnia bathypelagica are characteristic species of the Oceanic Community not penetrating the shelf water. Sagitta maxima is an abundant sub-Antarctic species (David 1958) and was almost absent in the Weddell Sea. In our study, the abundances of chaetognaths are probably underestimated, because individuals smaller than approximately $30 \mathrm{~mm}$ in length are not quantitatively sampled by the RMT 8 (Hagen 1985). 
Tunicata. The often observed patchy distribution of the tunicate Salpa thompsoni is caused by a small-scale rapid multiplication during times of sufficient food supply (Foxton 1966). Although the subsequent dense aggregations are well-known from other parts of the Southern Ocean, especially in oceanic regions (e.g., Mackintosh 1934; Foxton 1966; Piatkowski 1985a,b, Witek et al. 1985), only few large concentations were observed in the oceanic Weddell Sea. Appendicularians, numerous during January and February 1985 off the north-eastern coast (Hubold et al. 1988), were not encountered during our survey.

Vertebrata. Among the fish larvae the notothenioid Pleuragramma antarcticum is known as dominant species on the Weddell Sea shelf (Keller 1983; Hubold 1985). Distribution and abundance during February and March 1983 is described in detail by Hubold (1984). In the Southern Shelf Community the species was a main component of the macrozooplankton. Except for Aethotaxis mitopteryx all other notothenioids were caught in small numbers. The mesopelagic paralepidid Notolepis coatsi and the myctophids were typical species of the Oceanic Community.

\section{Community Analysis}

Most Antarctic zooplankton species are known to have a circumpolar and even distribution (e.g., Mackintosh 1934; Baker 1954). However, recent oceanographic studies in the Atlantic sector of the Southern Ocean demonstrate that bottom topography and water mass distribution disarrange this uniform distribution pattern: dense zooplankton concentrations occur at "shelf breaks" near Elephant Island (Shulenberger et al. 1984), at frontal systems like the Weddell-Scotia Confluence (Brinton et al. 1986; Nast 1986), and in shelf waters of the Palmer Archipelago (Witek et al. 1985). Moreover, it has been demonstrated that the patchy distribution of several Antarctic zooplankton species (e.g., Euphausia superba, Salpa thompsoni) intensifies their large-scale uneven distribution pattern (Hamner et al. 1983; Everson 1984).

The patchy distribution of zooplankton species is generally known to cause confusion in sampling pelagic communities (e.g., McGowan 1974; Haury et al. 1978). As Haury et al. (1978) emphasize, oceanographic surveys always investigate "true patterns" of the zooplankton distribution through a "sampling filter", which is caused by sampler selectivity, sampler efficiency and avoidance. These factors can strongly bias the "true patterns", hence the investigator receives "observed patterns" of the zooplankton distribution, which diverge from the "true patterns". Especially avoidance is an important source of error. Recently this was clearly proved for the RMT 8 (Everson and Bone 1986) which we used to collect zooplankton. Although this net is a relatively large gear to sample zooplankton, the authors conclusively showed the net avoidance of Euphausia superba during hauls at daylight. Large nets, however, possess a greater ability to detect rare species (McGowan and Fraundorf 1966) which is essential in each community study.

The communities outlined here comprise a relatively large area (Fig. 5). Antarctic plankton communities of similar range are analyzed by Rakusa-Suszczewski (1983), who established a "continental", an "antarctic" and an "intermediate" community off the Antarctic Peninsula considering distinct trophic relations and the dominance of certain taxa. Other community studies in the Southern Ocean are confined to distinct localities only. For example, Hardy and Gunther (1936) give a detailed synopsis of the zooplankton around South Georgia, Hopkins (1985a) analyzes the zooplankton community of Croker Passage, Antarctic Peninsula, Miller (1985) compares the macroplankton off the Prince Edward Islands and Gough Island, and Boden and Parker (1986) give a compilation of the plankton species occurring around the Prince Edward Islands.

Multivariate data analysis is now a well-established technique to analyze multispecies distribution patterns of extensive studies in marine environments (Field et al. 1982; Bölter and Meyer 1986). It has already been applied successfully to RMT 1 and RMT 8 data describing a mesopelagic community in the North East Atlantic (Domanski 1984). Especially cluster analysis is often used to analyze variability and community structure of zooplankton populations (e.g., Angel and Fasham 1973; Mackas and Anderson 1986; Sameoto 1986). Zooplankton community studies in the Southern Ocean using cluster analysis to search for biotic patterns were performed by Miller (1985) and recently by Hubold et al. (1988). By clustering RMT-data Miller (1985) detects a "marked faunal dissimilarity" between two sub-Antarctic islands (Prince Edward Islands and Gough Island, respectively), which he explains by hydrographic differences. Hubold et al. (1988) employ cluster analysis to compare zooplankton compositions of two target areas in the coastal waters of the Weddell Sea, and to test the sensivity of cluster analysis concerning reduction of the number of considered taxa to characterize the zooplankton communities obtained.

Cluster analysis applied to our extensive data sets from different stations divides the environment "Weddell Sea" into three subunits which represent different faunal regions (Figs. 4 and 5). The variability of the zooplankton species number and their relative dominance hierarchy cause this separation. The Southern Shelf Community comprises all stations situated on the large southern shelf. Depth profiles of water temperature and salinity show no obvious stratification of the water column (Fig. 2). The cold shelf water characterizes the epipelagic zone. Species abundances are low compared to the other communities. The Southern Shelf Community is dominated numerically by the copepod Metridia gerlachei and the calyptopis stages of Euphausia crystallorophias. However, they are not indicator species of this community, because they also appear quite frequently in the other 
communities (Fig. 6). The same applies to larvae and juveniles of Pleuragramma antarcticum and the pteropod Limacina helicina. Normally low in abundance, but typical for the near-continent fauna are several gammarids, which are known to live close to the bottom on the Antarctic shelf (Thurston 1974). Euphausia crystallorophias is a prevailing component of both shelf communities. Its dense concentrations have been already reported from other high-Antarctic shelf regions (RakusaSuszczewski and Stepnik 1980; Piatkowski 1985a).

Approximately at $75^{\circ} \mathrm{S} 27^{\circ} \mathrm{W}$, near Halley Bay, the main branch of the water masses flowing along the shelf edge in a south-westerly direction is deflected to the northwest to enter the Weddell gyre (Gill 1973; Carmack and Foster 1977; Fig. 3). South of Halley Bay only a narrow coastal current continues in a southerly direction, possibly responsible for the transport of several zooplankton species towards the southern shelf. The divergence zone of the currents acts as a border separating the Southern Shelf Community from the adjacent North-eastern Shelf Community.

The stations of the North-eastern Shelf Community are located on the narrow shelf of the north-eastern Weddell Sea. Its slope region is characterized by a convergence zone separating the cold shelf water from the warmer water masses of the Eastwind Drift. Therefore, both neritic and oceanic species contribute to this community and no indicator species can be identified. Trophic diversity is low compared to the other communities (Fig. 6), due to the very large portion of calanid copepodites (73.6\%) which represent the bulk of the filter feeders $(81.5 \%)$. The very large abundances of only few species is a striking phenomenon of this community. In community studies of the Weddell Sea regarding only macroplankton species (Piatkowski 1987; in press). Euphausia superba is the dominating euphausiid in the North-eastern Shelf Community. Some surprisingly rich krill samples $\left(>100\right.$ ind. $/ 1000 \mathrm{~m}^{3}$ ) have been yielded at the continental slope. Perhaps these dense aggregations indicate spawning grounds of the Weddell Sea krill. However, no sufficient numbers of eggs or metanauplii have been detected in February and March 1983 to confirm this assumption. Since spatial variability of plankton communities is most intense at continental margins and in areas where different water masses meet (e.g., Cushing 1961; Longhurst 1976), the heterogeneity of the northeastern Shelf Community is not surprising. A very narrow sampling grid would be necessary to distinguish between neritic and oceanic features. The Oceanic Community consists of the stations in the northern Weddell Sea and of those located over deep water off the northeastern coast (Fig. 5). In contrast to the other communities more species appear in moderate to large numbers. The share of gelatinous species, typical macroplankton components of the open sea, is significantly larger than in the shelf communities. They contribute several indicator species: e.g. Vogtia serrata, Atolla wyvillei. Thus, the Oceanic Community is largely identical with communities known from other oceanic regions in the Southern Ocean, e.g., the "antarctic" community as described by Rakusa-Suszczewski (1983). There are also great similarities to the zooplankton community in the Croker Passage (Hopkins 1985a). This is especially obvious for the copepods: Metridia gerlachei and Calanoides acutus - together with Euchaeta antarctica - form the major part of the zooplankton biomass in the Croker Passage (Hopkins 1985a). They are also numerically dominant components of the Oceanic Community in the Weddell Sea. Furthermore, the carnivorous cyclopoid copepods of the genera Oncaea and Oithona are characteristic forms of both, the community in the Croker Passage and the Oceanic Community. In both communities copepods largely outnumber euphausiids. However, Mujica and Torres (1983) show that in waters north of the Antarctic Peninsula the relation can be vice versa and they conclude that the groups exclude each other.

A striking difference to the shelf communities consists in the different portions of the feeding types (Fig. 6). In the Oceanic Community carnivores contribute $24 \%$, while their fraction is negligible in the shelf communities. The division of the coastal zooplankton community into a Southern and a North-eastern Community corresponds to two phytoplankton provinces described by Von Bröckel (1985) for the same time period. In both provinces, separated by the different percentages of the various size groupings of pennate diatoms, primary production is very high and supports efficient feeding grounds for herbivorous filter feeders. Therefore, it is not amazing that they contribute the main portion in the shelf communities whereas their quota in the Oceanic Community is comparatively low.

Summing up, the three communities we have introduced in the present study are characterized by different hydrographic conditions, different trophic diversities, and except for the North-eastern Shelf Community also by different indicator species. Species composition in each community certainly changes with season, however, similar situations are to be expected during each austral summer.

Acknowledgements. This paper is part of the authors' doctoral theses which were carried out at the Institute for Polar Ecology at Kiel University and supported by the Alfred-Wegener-Institute for Polar and Marine Research, Bremerhaven, F.R. Germany. Many thanks go to Drs. H.G. Andres, T. Brattegard, W. Hagen, I. Hempel, K. Hülsemann, H.G. Richter, C.F.E. Roper, S.B. Schiel, C. Støp-Bowitz, M. Türkay, H. Wägele and $\mathrm{R}$. Weigmann-Haass for introducing us into species taxonomy and for the identification of rare forms. We are indebted to Dr. M. Meyer providing us computer programs for multivariate data analysis. The authors also wish to thank Prof. G. Hempel, Drs. W. Hagen and G. Hubold for their helpful criticisms and constructive comments on the draft manuscript.

\section{References}

Alvariño A, Hosmer SC, Ford RF (1983a) Antarctic Chaetognatha: United States research program "Eltanin" cruises 8-28, part 1. Antarct Res Ser 34:129-338 
Alvariño A, Verfaillie DF, Ford RF (1983 b) Antarctic Chaetognatha: United States research program "Eltanin" cruises 10-23, 25, and 27, part 2. Antarct Res Ser 39:69-204

Andres HG (1978) Gammaridea (Amphipoda, Crustacea) der Antarktis-Expedition 1975/76 - Auswertung der Dauerstation südlich von Elephant Island. Meeresforschung 27:88-102

Andres HG (1986) Atylopsis procerus sp. n. und Cheirimedon solidus sp. n. aus der Weddell See sowie Anmerkungen zu Orchomenella pinguides Walker 1903 (Crustacea: Amphipoda: Gammaridea). Mitt Hamb Zool Mus Inst 83:117-130

Andrews KJH (1966) The distribution and life history of Calanoides acutus (Giesbrecht). Discovery Rep 34:117-162

Angel MV, Fasham MJR (1973) SOND cruise 1965: factor and cluster analysis of the plankton results, a general summary. J Mar Biol Assoc UK 53:185-231

Augener H (1929) Beiträge zur Planktonbevölkerung der Weddell See nach der Deutschen Antarktischen Expedition 1911-1912: 5. Die Polychaeten der Weddell See. Int Rev Ges Hydrobiol Hydrogr 22:273-311

Baker AdeC (1954) The circumpolar continuity of antarctic plankton species. Discovery Rep 26:201-218

Baker AdeC, Clarke MR, Harris MJ (1973) The N.I.O. Combination net (RMT 1-8) and further developments of rectangular midwater trawls. J Mar Biol Assoc UK 53:167-184

Biggs DC (1977) Field studies of fishing, feeding and digestion in siphonophores. Mar Behav Physiol 4:261-274

Birstein YA, Chindonova YG (1962) Mysidacea collected by the Soviet Antarctic Expedition on the RV "Ob". In: Andriyashev AP, Ushakov PV (eds) Biological reports of the Soviet Antarctic Expedition (1955-1958). Stud Mar Fauna 1:58-68

Birstein YA, Vinogradov ME (1962) Pelagic gammarids collected by the Soviet Antarctic Expedition with RV "Ob" southward from $40^{\circ} \mathrm{S}$. In: Andriyashev AP, Ushakov PV (eds) Biological reports of the Soviet Antarctic Expedition (1955-1958). Stud Mar Fauna 1:33-56

Boden BP, Parker LD (1986) The plankton of the Prince Edward Islands. Polar Biol 5:81-93

Bölter M, Meyer M (1986) Structuring of ecological data sets by methods of correlation and cluster analysis. Ecol Modelling 32:1-13

Bölter M, Meyer M, Probst B (1980) A statistical scheme for structural analysis in marine ecosystems. Ecol Modelling 9:143-151

Bollmann A (1934) Die Chaetognathen der Deutschen Antarktischen Expedition auf der Deutschland 1911-1912. Int Rev Ges Hydrobiol Hydrogr 30:251-305

Bowman TE (1985) The correct identity of the pelagic amphipod Primno macropa, with a diagnosis of Primno abyssalis (Hyperiidea: Phrosinidae). Proc Biol Soc Wash 98:121-126

Boysen-Ennen E (1987) On the distribution of meso- and macrozooplankton in the surface water of the Weddell Sea (in German). Rep Polar Res 35:1-126

Brinton E, Huntley M, Townsend AW (1986) Larvae of Euphausia superba in Scotia Sea and Bransfield Strait in March 1984 - Development and abundance compared with 1981 larvae. Polar Biol $5: 221-234$

Bröckel K von (1985) Primary production data from the southern Weddell Sea. Polar Biol 4:75-80

Carmack EC, Foster TD (1975) Circulation of oceanographic properties near the Filchner Ice Shelf. Deep-Sea Res 22:77-90

Carmack EC, Foster TD (1977) Water masses and circulation in the Weddell Sea. In: Dunbar MJ (ed) Polar Oceans. Arct Inst North America, pp 151-165

Chen C (1968) Zoogeography of thecosomatous pteropods in the West Antarctic Ocean. Nautilus 81:94-101

Conover RJ, Lalli CM (1972): Feeding and growth in Clione limacina, a pteropod mollusc. J Exp Mar Biol Ecol 9:279-302

Cushing DH (1961) Patchiness. ICES Rapp Proc Verb 153:152-163

David PM (1958) The distribution of the Chaetognatha of the Southern Ocean. Discovery Rep 29:200-229

Deevey GB, Brook A (1977) Copepods of the Sargasso Sea off Bermuda: Species composition, and vertical and seasonal distribution between the surface and $2000 \mathrm{~m}$. Bull Mar Sci 27:256-291

Domanski P (1984) The diel migrations and distributions within a mesopelagic community in the North-East Atlantic. 8. A multivariate analysis of community structure. Prog Oceanogr 13:491-511

Drescher HE, Hubold G, Piatkowski U, Voß J (1983) Das biologische Programm der Antarktis-I-Expedition mit FS Polarstern: Stationslisten der Plankton-, Benthos- und Grundschleppnetzfänge und der Liste der Probennahme an Robben und Vögeln. Rep Polar Res 13:1-34

Ehlers E (1913) Die Polychaeten der Deutschen Südpolar-Expedition 1901 - 1903. Dtsch Süidpolar Exp 13:397-598

El-Sayed SZ, Taguchi S (1981) The primary production and standing crop of phytoplankton along the ice-edge in the Weddell Sea. DeepSea Res 28:1017-1032

Everson I (1984) Zooplankton. In: Laws RM (ed) Antarctic ecology, vol II. Academic Press, London, pp 463-490

Everson I, Bone DG (1986) Effectiveness of RMT 8 system for sampling krill (Euphausia superba) swarms. Polar Biol 6:83-90

Farran GP (1929) Crustacea. Part X. Copepoda. Nat Hist Rep Br Antarct "Terra Nova" Exp 8:203-306

Fevolden SE (1979) Investigation on krill (Euphausiacea) sampled during the Norwegian Antarctic Research Expedition 1976/77. Sarsia 64:189-198

Fevolden SE (1980) Krill off Bouvetöya and in the southern Weddell Sea with a description of larval stages of Euphausia crystallorophias. Sarsia 65:149-162

Field JG, Clarke KR, Warwick RM (1982) A practical strategy for analysing multispecies distribution patterns. Mar Ecol Prog Ser $8: 37-52$

Foxton P (1966) The distribution and life history of Salpa thompsoni Foxton with observations on a related species Salpa gerlachei. Discovery Rep 34:1-116

Frost B, Fleminger A (1968) A revision of the genus Clausocalanus (Copepoda: Calanoida) with remarks on distributional patterns in diagnostic characters. Bull Scripps Inst Oceanogr 12:1-235

Gill AE (1973) Circulation and bottom water production in the Weddell Sea. Deep-Sea Res 20:111-140

Gilmer RW (1974) Some aspects of feeding in thecosomatous pteropod molluscs. J Exp Mar Biol Ecol 15:127-144

Hagen W (1985) On distribution and population structure of Antarctic Chaetognatha. Meeresforschung 30:280-291

Hamner WM, Hamner PP, Strand SW, Gilmer RW (1983) Behavior of Antarctic krill, Euphausia superba: chemoreception, feeding, schooling, and molting. Science 220:433-435

Harbison GR, Biggs DC, Madin LP (1977) Associations of Amphipoda Hyperiidea with gelatinous zooplankton. II. Associations with cnidaria, ctenophora and radiolaria. Deep-Sea Res 24:465-488

Hardy AC, Gunther ER (1936) The plankton of the South Georgia whaling grounds and adjacent waters 1926-1927. Discovery Rep $11: 1-456$

Hartman O (1964) Polychaeta Errantia of Antarctica. Antarct Res Ser $3: 1-131$

Haury LR, McGowan JA, Wiebe PH (1978) Patterns and processes in the time-space scale of plankton distributions. In: Steele JH (ed) Spatial pattern in plankton communities. Plenum Press, New York, pp $277-327$

Hempel G (1983) Die Expedition Antarktis I mit FS Polarstern 1982/83. Rep Polar Res 14:1-141

Hempel G (1987) The krill-dominated pelagic system of the Southern Ocean. Environ Int 13:33-36

Hempel I, Hempel G (1982) Distribution of euphausiid larvae in the southern Weddell Sea. Meeresforschung 29:253-266

Hempel I, Hubold G, Kaczmaruk B, Keller R, Weigmann-Haass R (1983) Distribution of some groups of zooplankton in the inner Weddell Sea in summer 1979/80. Rep Polar Res 9:1-35

Heron GA, Bowman TE (1971) Postnaupliar developmental stages of the copepod crustaceans Clausocalanus laticeps, Clausocalanus brevipes, and Clausocalanus citer (Calanoida: Pseudocalanidae). Antarct Res Ser 17:141-165

Hopkins TL (1985a) The zooplankton community of Croker Passage, Antarctic Peninsula. Polar Biol 4:161-170

Hopkins TL (1985b) Food web of an antarctic midwater ecosystem. Mar Biol 89:197-212 
Hopkins TL (1987) Midwater food web in McMurdo Sound, Ross Sea, Antarctica. Mar Biol 96:93-106

Hubold G (1984) Spatial distribution of Pleuragramma antarcticum (Pisces: Nototheniidae) near the Filchner and Larsen Ice Shelves (Weddell Sea/Antarctica). Polar Biol 3:231-236

Hubold G (1985) On the early life history of the high Antaretic silverfish Pleuragramma antarcticum. In: Siegfried WR, Condy PR, Laws RM (eds) Antarctic nutrient cycles and food webs. Proc 4th SCAR Symp Antarct Biol. Springer, Berlin, pp 445-451

Hubold G, Hempel I (1987) Seasonal variability of zooplankton in the Southern Weddell Sea. Meeresforschung 31:185-192

Hubold G, Hempel I, Meyer M (1988) Zooplankton communities in the southern Weddell Sea. Polar Biol 8:225-233

Jazdzewski K, Kittel W, Lotocki K (1982) Zooplankton studies in the southern Drake Passage and in the Bransfield Strait during the austral summer (BIOMASS-FIBEX, February-March 1981). Pol Polar Res 3:203-242

Kaczmaruk BZ (1983) Occurrence and distribution of the antarctic copepods along the ice shelves in the Weddell Sea in summer 1979/80. Meeresforschung 30:25-41

Kane JE (1966) The distribution of Parathemisto gaudichaudii (Guer) with observations on its life history in the $0^{\circ}$ to $20^{\circ} \mathrm{E}$ sector of the Southern Ocean. Discovery Rep 34:163-198

Keller R (1983) Contributions to early life history of Pleuragramma antarcticum. Meeresforschung 30:10-24

Kellermann A (1987) Food and feeding ecology of postlarval and juvenile Pleuragramma antarcticum (Pisces; Notothenioidei) in the seasonal pack ice zone off Antarctic Peninsula. Polar Biol 7:307-315

Kils U (1983) Swimming and feeding of Antarctic krill Euphausia superba - some outstanding energetics and dynamics, some unique morphological details. Rep Polar Res (Spec Issue) 4:130-155

Kirkwood JH (1983) A guide to the decapoda of the Southern Ocean. Anare Res Notes 11:1-47

Kittel W (1980) Population studies on Euphausia superba Dana 1852 (Euphausiacea, Crustacea) in waters of the Admirality Bay during Antarctic summer of 1978. Pol Arch Hydrobiol 27:267-272

Kittel W, Ligowski R (1980) Algae found in the food of Euphausia crystallorophias (Crustacea). Pol Polar Res 1:129-137

Kittel W, Presler P (1980) Morphology of the postlarval development stages of Euphausia crystallorophias Holt \& Tattersall 1906 (Euphausiacea, Crustacea). Pol Arch Hydrobiol 27:259-265

Kramp PL (1959) The hydromedusae of the Atlantic Ocean and adjacent waters. Dana Rep 46:1-128

Kramp PL (1968) The hydromedusae of the Pacific and Indian Ocean, Section II and III. Dana Rep 72:1-200

Lance GN, Williams WT (1967) A general theory of classificatory sorting strategies. 1. Hierarchical systems. Comput J 9:373-379

Lebour MV (1935) The echinospira larvae (Mollusca) of Plymouth. Proc Zool Soc London 35:163-174

Lohmann H (1928) Beiträge zur Planktonbevölkerung der Weddell See: II. Die Appendicularien-Bevölkerung der Weddell See. Int Rev Ges Hydrobiol Hydrogr 20:13-34

Longhurst AR (1976) Vertical migration. In: Cushing DH, Walsh JJ (eds) The ecology of the seas. Blackwell, Oxford, pp 116-137

Mackas DL, Anderson EP (1986) Small scale zooplankton community variability in a northern British Columbia fjord system. Estuarine Coastal Shelf Sci 22:115-135

Mackintosh NA (1934) Distribution of the macroplankton in the Atlantic sector of the Antarctic. Discovery Rep 9:65-160

Mackintosh NA (1970) Whales and krill in the twentieth century. In: Holdgate MW (ed) Antarctic ecology, vol I. Academic Press, London, pp 195-212

Makarov RR (1979) Larval distribution and reproductive ecology of Thysanoessa macrura (Crustacea: Euphausiacea) in the Scotia Sea. Mar Biol 52:377-386

Marr JWS (1962) The natural history and geography of the Antarctic krill (Euphausia superba Dana). Discovery Rep 32:33-464

Marshall SM, Orr AP (1956) On the feeding biology of Calanus finmarchicus: IX. Feeding and digestion in the young stages. J Mar Biol Assoc UK 35:587-603
McGowan JA (1974) The nature of oceanic ecosystems. In: Miller C (ed) The biology of the oceanic Pacific. Oregon State University Press, Corvallis, Oregon, pp 9-22

McGowan JA, Fraundorf VJ (1966) The relationship between size of net used and estimates of zooplankton diversity. Limnol Oceanogr $11: 456-459$

Miller DGM (1985) Marine macroplankton of two subantarctic islands. In: Siegfried WR, Condy PR, Laws RM (eds) Antarctic nutrient cycles and food webs. Proc 4th SCAR Symp Antarct Biol. Springer, Berlin, pp 355-361

Montú MA, Oliveira IR de (1986) Zooplanktonic associations, trophic relations and standing stock of krill and other groups of the community near Elephant Island (February-March 1984-1985). Neritica 1:111-130

Morton JE (1954) The biology of Limacina retroversa. J Mar Biol Assoc UK 33:297-312

Moser F (1925) Die Siphonophoren der Deutschen Südpolar-Expedition 1901-1903. Dtsch Südpolar Exp 17:1-541

Mujica AR, Torres AG (1983) Qualitative and quantitative analysis of the Antarctic zooplankton. INACH Ser Sci 28:165-174

Nakamura M, Kadota S, Fukuchi M (1982) Epipelagic copepods of Calanoida in the Indian sector of the Antarctic ocean. In: Hoshiai T, Naito Y (eds) Proc 5th Symp Antarct Biol. Mem Natl Inst Polar Res (Spec Issue) 23:28-31

Nast F (1986) Changes in krill abundance and in other zooplankton relative to the Weddell-Scotia Confluence around Elephant Island in November 1983, November 1984 and March 1985. Arch Fischereiwiss 37:73-94

Ommanney FD (1936) Rhincalanus gigas (Brady), a copepod of the southern macroplankton. Discovery Rep 13:277-384

Orensanz JM, Ramírez FC, Dinofrio EO (1974) Resultados planctológicòs de la compaña "Oceantar I": II. Poliquetos. Contrib Inst Antarct Arg 184:1-41

O'Sullivan D (1982) A guide to the polychaetes of the Southern Ocean and adjacent waters. ANARE Res Notes 3:1-62

Ottestad P (1932) On the biology of some southern copepods. Hvalrad Skr $5: 1-61$

Ottestad P (1936) On antarctic copepods from the "Norvegia" Expedition 1930-31. Sci Res "Norvegia" Exped 1927-1928 et sqq 15:5-44

Park T (1978) Calanoid copepods from antarctic and subantarctic waters (Euchaetidae and Aetideidae). Antarct Res Ser 27:91-290

Park T (1982) Calanoid copepods of the genus Scaphocalanus from antarctic and subantarctic waters. Antaret Res Ser 34:75-127

Petipa TS, Pavlova EV, Mironov GN (1970) The food web structure and transport of energy by trophic levels in the planktonic community. In: Steele JH (ed) Marine food chains. Oliver and Boyd, Edinburgh, pp 142-167

Piatkowski U (1985a) Distribution, abundance and diurnal migration of macrozooplankton in antarctic surface waters. Meeresforschung 30:264-279

Piatkowski U (1985b) Maps of the geographical distribution of macrozooplankton in the Atlantic sector of the Southern Ocean. Rep Polar Res 22:1-55

Piatkowski U (1987) Zoogeographical investigations and community analyses on antarctic macroplankton (in German). Rep Polar Res $34: 1-150$

Piatkowski U (in press) Macrozooplankton communities from Weddell Sea surface waters, Antarctica. Proc 2nd Int Symp Antarct Biol, Rio de Janeiro. Ann Acad Bras Cienc

Picken GB (1980) Reproductive adaptations of antarctic benthic invertebrates. Biol J Linnean Soc 14:67-75

Plötz J (1986) Summer diet of Weddell seals (Leptonychotes weddelli) in the eastern and southern Weddell Sea, Antarctica. Polar Biol $6: 97-102$

Rakusa-Suszczewski S (1982) The biology and metabolism of Orchomene plebs (Hurley 1965) (Amphipoda: Gammaridea) from McMurdo Sound, Ross Sea, Antarctica. Polar Biol 1:47-54

Rakusa-Suszczewski S (1983) The relationship between the distribution of plankton biomass and plankton communities in the Drake Passage and the Bransfield Strait (BIOMASS-FIBEX, February-March 
1981) In: Nemoto T, Makuda T (eds) Proc BIOMASS Colloq 1982. Mem NatI Inst Polar Res (Spec Issue) 27:77-83

Rakusa-Suszczewski S, Stepnik R (1980) Three species of krill from Admirality Bay (King George, South Shetlands) in summer 1978/79. Pol Arch Hydrobiol 27:273-284

Rodhouse PG, Clarke MR (1986) Distribution of the early life phase of the antarctic squid Galiteuthis glacialis in relation to the hydrology of the Southern Ocean in the sector $15^{\circ}$ to $30^{\circ} \mathrm{E}$. Mar Biol 91:353-357

Roe HSJ, Shale DM (1979) A new multiple Rectangular Midwater Trawl (RMT $1+8 \mathrm{M}$ ) and some modifications to the Institute of Oceanographic Sciences' RMT 1+8. Mar Biol 50:283-288

Roe HSJ, Baker AdeC, Carson RM, Wild R, Shale DM (1980) Behaviour of the Institute of Oceanographic Science's Rectangular Midwater Trawls: Theoretical aspects and experimental observations. Mar Biol 56:247-259

Rosendorn I (1927) Die Gattung Oithona. Dtsch Tiefsee Exp $1898-189923: 1-55$

Ruud JT (1932) On the biology of the southern euphausiidae. Hvalrad Skr 2:1-105

Sakshaug E, Holm-Hansen O (1984) Factors governing pelagic production in polar oceans. In: Holm-Hansen O, Bolis L, Gilles R (eds) Marine phytoplankton and productivity, vol 8 . Lecture notes on coastal and estuarine studies, $1-18$

Sameoto DD (1984) Environmental factors influencing diurnal distribution of zooplankton and ichthyoplankton. J Plankton Res 6:767-792

Sameoto DD (1986) Influence of the biological and physical environment on the vertical distribution of mesozooplankton and micronekton in the eastern tropical Pazific. Mar Biol 93:263-279

Schnack SB (1983) Feeding of two Antarctic copepod species (Calanus propinquus and Metridia gerlachei) on a mixture of centric diatoms. Polar Biol 2:63-69

Schnack SB, Marschall S, Mizdalski E (1985) On the distribution of copepods and larvae of Euphausia superba in Antarctic waters during February 1982. Meeresforschung 30:251-263

Shulenberger E, Wormuth JH, Loeb VJ (1984) A large swarm of Euphausia superba: overview of patch structure and composition. $\mathbf{J}$ Crust Biol 4:75-95

Siegel V (1982) Investigations on krill (Euphausia superba) in the southern Weddell Sea. Meeresforschung 29:244-252

Slattery PN, Oliver JS (1986) Scavenging and other feeding habits of lysianassid amphipods (Orchomene spp.) from McMurdo Sound, Antarctica. Polar Biol 6:171-177

Spoel S van der (1967) Euthecosomata, a group with remarkable developmental stages. Nat Diss, Amsterdam. Noorduyn en Zoon, Gorinchem, pp 1-375

Steuer A (1937) Die Verbreitung der Copepoden-Gattungen Sapphirinano, Copilia, Miracia; Pleuromamma, Rhincalanus und Cephalophanes im Südatlantischen Ozean. Wiss Ergeb Dtsch Atlant Exp Meteor 12:101-163

Støp-Bowitz C (1977) Polychètes pélagique des expéditions du "Willem Barendsz" et du "Snellius". Zool Med 51:1-24

Strübing K (1982) Die Zugänglichkeit von Forschungsstationen am Rande der Weddell See in Abhängigkeit von den Meereisverhältnissen. Proc INTERMARITEC 1982, Hamburg 29-30 September 1982, pp $1-15$

Tebble N (1960) The distribution of pelagic polychaetes in the South Atlantic Ocean. Discovery Rep 30:161-300
Tebble N (1968) Pelagic polychaetes of the Soviet Antarctic Expeditions. In: Andriyashev AP, Ushakov PV (eds) Biological reports of the Soviet Antarctic Expeditions 1955-1958. Stud Mar Fauna 4:23-32

Thiel ME (1931) Beiträge zur Planktonbevölkerung der Weddell See. VI. Die Hydromedusen der Weddell See. Int Rev Ges Hydrobiol Hydrogr 25:305-332

Thurston MH (1974) Crustacea Amphipoda from Graham Land and the Scotia Arc, collected by operation Tabarin and the Falkland Islands Dependencies Survey, 1944-59. Sci Rep Br Antarct Surv 85:1-89

Timonin AG (1973) Structure of pelagic communities: Trophic structure of zooplankton in the northern part of the Indian Ocean. Oceanology 13:85-93

Totton AK, Bargmann HE (1965) A synopsis of the Siphonophora. $\mathrm{Br}$ Mus Nat Hist, London, pp 1-230

Tranter DJ (1982) Interlinking of physical and biological processes in the Antarctic Ocean. Oceanogr Mar Biol Annu Rev 20:11-36

Vervoort W (1951) Plankton copepods from the Atlantic sector of the Antarctic. K Ned Akad Wet, Versl Gewone Vergad Afd Natuurkd Dl 48:1-156

Vervoort W (1965) Notes on the biogeography and ecology of freeliving marine copepods. In: Mieghem $J$ van, Oye $P$ van, Schell J (eds) Biogeography and ecology in Antarctica. W Junk Publishers, The Hague, pp $381-400$

Vladimirskaya YV (1978) Age composition of winter populations of abundant species in the southern part of the Scotia Sea. Oceanology 18:202-204

Voronina NM (1970) Seasonal cycles of some common Antarctic copepod species. In: Holdgate NM (ed) Antarctic ecology, vol I. Academic Press, London, pp 162-172

Voronina NM (1972a) The spatial structure of interzonal copepod population in the Southern Ocean. Mar Biol 15:336-343

Voronina NM (1972b) Vertical structure of a pelagic community in the Antarctic. Oceanology 12:415-420

Voss NA (1980) A generic revision of the chranchiidae (Cephalopoda: Oegopsida). Bull Mar Sci 30:365-412

Ward P (1985) On the biology of Antarctomysis ohlini (Crustacea: Mysidacea) at South Georgia. Br Antarct Surv Bull 67:13-23

Weigmann-Haass R (1983) Zur Taxonomie und Verbreitung der Gattung Cyllopus Dana 1853 (Amphipoda: Hyperiidea) im antarktischen Teil des Atlantik. Meteor Forsch-Ergeb (Reihe D) 36:1-11

Wickstead JH (1962) Food and feeding in pelagic copepods. Proc Zool Soc London 139:545-555

Witek Z, Kittel I, Czykieta H, Zmijewska I, Presler E (1985) Macrozooplankton in the southern Drake Passage and in the Bransfield Strait during BIOMASS-SIBEX (December 1983-Januar 1984). Pol Polar Res 6:95-115

Wolfenden RN (1911) Die marinen Copepoden der Deutschen Südpolar-Expedition 1901-1903. II. Die pelagischen Copepoden der Westwinddrift und des südlichen Eismeeres. Dtsch Südpolar Exp $12: 181-380$

Yaldwyn JC (1965) Antarctic and subantarctic decapod crustacea. In: Mieghem J van, Oye P van, Schell J (eds) Biogeography and ecology in Antarctica. W Junk Publishers, The Hague, pp 324-332

Zmijewska MI (1983) Copepoda (Calanoida) from Prydz Bay (Antarctica, Indian Ocean Sector). Pol Polar Res 4:33-47

Zmijewska MI (1985) Copepoda in the southern part of Drake Passage and in Bransfield Strait during early summer 1983-84 (BIOMASS. SIBEX, December-January). Pol Polar Res 6:79-93 